University of Nebraska - Lincoln

DigitalCommons@University of Nebraska - Lincoln

Response of sunshine bass (Morone chrysops $x$ M. saxatilis) to digestible protein/ dietary lipid density and ration size at summer culture temperatures in the Southern United States

\author{
Steven D. Rawles \\ USDA-ARS, steven.rawles@ars.usda.gov \\ Barholomew W. Green \\ USDA-ARS \\ T. Gibson Gaylord \\ U.S. Fish and Wildlife Service \\ Frederic T. Barrows \\ USDA-ARS, Rick.Barrows@ars.usda.gov \\ Matthew W. McEntire \\ USDA-ARS
}

See next page for additional authors

Follow this and additional works at: https://digitalcommons.unl.edu/usdaarsfacpub

Rawles, Steven D.; Green, Barholomew W.; Gibson Gaylord, T.; Barrows, Frederic T.; McEntire, Matthew W.; and Freeman, Donald W., "Response of sunshine bass (Morone chrysops $x$ M. saxatilis) to digestible protein/ dietary lipid density and ration size at summer culture temperatures in the Southern United States" (2012). Publications from USDA-ARS / UNL Faculty. 1396.

https://digitalcommons.unl.edu/usdaarsfacpub/1396

This Article is brought to you for free and open access by the U.S. Department of Agriculture: Agricultural Research Service, Lincoln, Nebraska at DigitalCommons@University of Nebraska - Lincoln. It has been accepted for inclusion in Publications from USDA-ARS / UNL Faculty by an authorized administrator of DigitalCommons@University of Nebraska - Lincoln. 


\section{Authors}

Steven D. Rawles, Barholomew W. Green, T. Gibson Gaylord, Frederic T. Barrows, Matthew W. McEntire, and Donald W. Freeman 


\title{
Response of sunshine bass (Morone chrysops $x$ M. saxatilis) to digestible protein/ dietary lipid density and ration size at summer culture temperatures in the Southern United States
}

\author{
Steven D. Rawles ${ }^{\text {a,* }}$, Bartholomew W. Green ${ }^{\text {a }}$, T. Gibson Gaylord ${ }^{\text {b }}$, Frederic T. Barrows ${ }^{c}$, \\ Matthew E. McEntire ${ }^{a}$, Donald W. Freeman ${ }^{a}$ \\ a United States Department of Agriculture (USDA), Agricultural Research Service (ARS) - Harry K. Dupree Stuttgart National Aquaculture Research Center, P.O. Box 1050, Stuttgart, \\ Arkansas, 72160-1050 USA \\ ${ }^{\mathrm{b}}$ U.S. Department of the Interior, Fish and Wildlife Service, Bozeman Fish Technology Center, 4050 Bridger Canyon Road, Bozeman, Montana 59715 USA \\ c USDA, ARS, Small Grains and Potato Germplasm Research Unit, Hagerman Fish Culture Experiment Station, 3059F National Fish Hatchery Road, Hagerman, Idaho 83332 USA
}

\section{A R T I C L E I N F O}

Article history:

Received 30 September 2011

Received in revised form 18 May 2012

Accepted 22 May 2012

Available online 29 May 2012

Keywords:

Hybrid striped bass

Ration size

Protein and energy utilization

Temperature

\begin{abstract}
A B S T R A C T
Temperature and ammonia levels often increase dramatically in ponds during summer production of sunshine bass and summer temperatures are projected to increase in the Southern US. Extended periods of high ammonia result in fish stress, disease, mortality and significant loss of feeding days as producers attempt to reduce ammonia to manageable levels through reduced feeding or lower protein diets. A factorial feeding trial was conducted in temperature controlled tanks to investigate main and interactive effects of three digestible protein (DP) levels (33, 40, 47\%), two lipid levels (10,18\%) and two ration levels (full fed: satiation, restricted: $80 \%$ of satiation) on growth, body composition, nutrient and amino acid retention, and ammonia and phosphorus excretion in sunshine bass (mean weight: $75 \mathrm{~g}$ ) reared at elevated temperature $\left(30.5 \pm 0.5^{\circ} \mathrm{C}\right)$. Diets were balanced on an available amino acid basis to the profile of hybrid striped bass muscle and supplemented with lysine and methionine at the equivalent of 330, 400, or $470 \mathrm{~g} / \mathrm{kg}$ of muscle protein. Each DP x lipid x ration treatment was fed to triplicate tanks of fish for 116 days. All measured responses were significantly altered by main and interactive effects, but the patterns of interaction were similar among responses. Restricted feeding resulted in much lower final weights and weight gains but much higher ammonia excretion as a function of feed or $\mathrm{N}$ fed and body weight (BW), regardless of DP level. Lower dietary fat (10\%) resulted in lower weight gains and poorer feed conversions as well as higher ammonia excretion (per g N fed/kg BW) regardless of DP or ration level. Weight gain (475\%) and final fish weight ( $434 \mathrm{~g}$ ) were highest at $47 \% \mathrm{DP} / 18 \%$ dietary lipid, but feed conversion, protein, energy and amino acid retention efficiencies were markedly poorer in the $47 \%$ DP diets regardless of lipid level due to hyperphagia in fish fed this diet. The 40/18 diet consistently outperformed the 33/18 diet in better growth and lower ammonia excretion as a function of $\mathrm{N}$ fed/ BW, and nearly equaled the growth attained by fish fed $47 / 18$ diet. Increasing ration to satiation at elevated temperature resulted in much greater improvements in weight gain, final weight and ammonia excretion of fish fed the 40/18 diet, as opposed to those fed the 33/18 diet. Amino acid retentions were nearly equal between the $33 / 18$ and $40 / 18$ diets and restricting feed to $80 \%$ of satiation slightly improved feed conversions and protein and amino acid retentions. Consistent lipid x DP interactions generally indicated that the differences among responses to DP level seen at $18 \%$ dietary lipid significantly decreased or disappeared at $10 \%$ dietary lipid. Phosphorus excretion was low and not significantly altered by main effects. Results suggest that a producer desiring to reduce pond ammonia with the least compromise to production efficiency would be better served by feeding a $40 \%$ DP/ $18 \%$ lipid diet at a reduced level instead of switching to a lower protein diet.
\end{abstract}

Published by Elsevier B.V.

\section{Introduction}

Summer temperatures in hybrid striped bass (Morone chrysops $x$ M. saxatilis) production ponds can reach extremes $\left(29-33^{\circ} \mathrm{C}\right)$. As a result of peak feeding during this season, high total ammonia-

\footnotetext{
* Corresponding author. Tel.: +1 870673 4483; fax: +1 8706737710 . E-mail address: steven.rawles@ars.usda.gov (S.D. Rawles).
}

nitrogen (TAN) and concomitantly lower dissolved oxygen typically reduce feed consumption in an episodic manner and increase the potential for stress, disease, and mortality. Analysis of two-years of production and water quality data from a large sunshine bass producer, for example, revealed that $60 \%$ of all ponds experienced TAN greater than 1.5 ppm for eight weeks or more in 2007 - 2008, while $23 \%$ of ponds experienced TAN greater than $2.0 \mathrm{ppm}$ (Max Rapert, Nature's Catch, Inc., personal communication). In some ponds, TAN levels reached 4-6 ppm for several days. 
Growth of hybrid striped bass is adversely affected by daily exposure to about $1.8 \mathrm{ppm}$ total ammonia nitrogen (TAN) at pH 9.0 (Hargreaves and Kucuk, 2001), while daily exposure to 2.5 ppm TAN ( $\mathrm{pH}=9.0$ ) can lead to mortality. When levels reach approximately 3 ppm TAN, sufficient ammonia is in the unionized form to cause mortality. Hence, producers curtail or cease feeding when TAN concentrations remain elevated, until levels drop below some predetermined management threshold. On the farm cited above, this practice translated into $56 \%$ of the pond acreage receiving at least $25 \%$ less than the maximum potential feed allotment during the peak production season, based on the producer's pond inventories.

Evidence is also accruing that population dynamics of natural moronid stocks are being impacted by global warming (Hanks and Secor, 2011). With temperatures predicted to rise approximately $0.2^{\circ} \mathrm{C}$ per decade in mid-Atlantic to southern states (Najjar et al., 2010), there is mounting impetus to reexamine hybrid striped bass nutrient requirements and feed formulas in order to maximize production efficiency, minimize excretion of dietary nutrients and their impact on water quality, and insure industry longevity in the face of climate change.

Typical commercial grow-out diets for hybrid striped bass contain $40 \%$ crude protein and $10-12 \%$ lipid. While there is a plethora of research on the effects of water temperature on various fish responses, few studies have included ration level and/or diet composition as independent variables. For example, Buentello et al. (2000) found significant predictive relationships between feed consumption, feed utilization or growth with respect to water temperature and dissolved oxygen when channel catfish (Ictalurus punctatus) were raised in temperature profiles mimicking spring/summer increases in Southern U.S. ponds. Carter et al. (2006) examined Atlantic salmon (Salmo salar) production with respect to dietary protein, energy, fatty acid profile, and fishmeal content at elevated temperature. Guerreiro et al. (2011) measured growth and nutrient utilization of Senegalese sole (Solea sengalensis) in response to dietary protein:lipid ratio at elevated temperature and Green et al. (2011) also found formula changes were needed to optimize diets for African abalone (Haliotis midae) at elevated temperature.

In sunshine bass only one study has focused on diet performance with respect to elevated culture temperature. Rawles et al. (2010) reared juvenile hybrid striped bass at $32{ }^{\circ} \mathrm{C}$ for 4 weeks in a $2 \times 2$ factorial study designed to test two different crude protein levels (35\% vs. $40 \%$ ) and two different dietary lipid levels (10\% vs. $15 \%$ ). Fish grew from $100 \mathrm{~g}$ to nearly $200 \mathrm{~g}$ and average daily gain and final fish weight increased with diet protein level but not lipid level in the diet, though the study was short in duration and may not have been long enough to allow full expression of all treatment effects. Feed efficiencies, however, increased with both dietary protein and lipid level. Since the diets in that study were off-the-shelf commercial formulations based on crude protein level, the results suggested that higher digestible protein and dietary lipid levels may be needed when hybrid striped bass are reared at elevated temperature.

Hence, the objective of the current study was to investigate the factorial effects of dietary protein level, lipid level and feed ration (full fed vs. restricted feeding) on growth, composition of growth, nutrient and energy retention, and ammonia and phosphorus excretion in sunshine bass reared at elevated temperature (30.5 C). We hypothesized that growth of hybrid striped bass could be optimized at high culture temperatures by reducing the protein:energy ratios of the diet. This would meet increased metabolic energy demands of the fish using non-protein energy substrates while reducing nitrogenous waste excretion.

\section{Materials and methods}

\subsection{Experimental design, fish, and culture system}

The feeding trial was conducted in tanks at the USDA/ARS - Harry K. Dupree Stuttgart National Aquaculture Research Center (HKDSNARC;
Stuttgart, AR) over a 116 day period from May 28 to October 2, 2010. Diets were fed in a $3 \times 2 \times 2$ factorial design to triplicate tanks of sunshine bass to test the main and interactive effects of three digestible protein levels $(33,40,47 \%)$, two lipid levels $(10,18 \%)$ and two ration levels (full fed, restricted) at elevated temperature $\left(30.5 \pm 0.5^{\circ} \mathrm{C}\right)$. Sunshine bass averaging $75.4 \pm 0.4 \mathrm{~g}( \pm \mathrm{SD})$ were individually marked with passive integrated transponder (PIT) tags (Biomark, Inc., Boise, ID) in the dorsal musculature and randomly stocked ( 20 fish/tank) into 36 insulated, circular fiberglass tanks in a temperature controlled room. Tanks $\left(0.25 \mathrm{~m}^{3}\right)$ were supplied with heated, aerated flow-through freshwater at the rate of $2.5 \mathrm{~L} / \mathrm{min}$ per tank. Well water was first passed through a gas-fired boiler (Iron Fireman Model 36-50-63, Franklin Park, IL) and the heated water subsequently mixed with unheated well water via a computer controlled mixing valve (Intellifaucet ${ }^{\mathrm{TM}}$ Model K750, Hass Manufacturing, Averill Park, NY) to achieve the desired culture temperature.

The final culture temperature in the study of $30.5\left( \pm 0.5^{\circ} \mathrm{C}\right)$ was based on the median daily pond temperature recorded from June through August during 2007 and 2008 on a commercial hybrid striped bass farm (Nature's Catch, Clarksdale, MS). Temperature in each tank was monitored hourly for $24 \mathrm{~h}$ on alternate days by automated temperature loggers (HOBO Water Temp Pro v2, Onset Computer Corp., Pocasset, MA) assigned to pairs of tanks. Temperature loggers were switched to their alternate tank at 0800 daily and the data was downloaded weekly to monitor system thermal stability. Fish were initially acclimated to the culture system on ambient well water $\left(24^{\circ} \mathrm{C}\right)$ for one week prior to initiation of the experiment. During the acclimation period, fish were fed a standard commercial $40 \%$ protein / $12 \%$ lipid hybrid striped bass feed (Cargill Nutrition, Franklinton, LA) at 1.5\% of body weight to maintain good condition with minimal growth. At the onset of test diet feeding, water temperature remained at $24^{\circ} \mathrm{C}$ for an additional week and was then increased $0.5^{\circ} \mathrm{C} \mathrm{d}^{-1}$ to the final culture temperature over a 14-d period to avoid stress and simulate summer temperature rises found in production ponds of the Southern United States.

To insure the culture system maintained acceptable water quality at the elevated temperature, dissolved oxygen (DO), $\mathrm{pH}$, and total ammonia nitrogen (TAN) were intensively monitored throughout the trial in order to capture the extreme ranges of those parameters based on pre-trial experience with the culture system, fish density, and ration loads employed in the current study. DO and $\mathrm{pH}$ were measured every other day in each tank at $0800-0900$ am and $2-4 \mathrm{~h}$ postprandial using a hand-held meter (Model HQ40D portable DO/pH meter, Hach, Inc. Loveland, CO). TAN was measured in water samples collected from each tank on alternate days at 0800-0900 am and 3-5 h postprandial using the Nessler Method on a portable spectrophotometer (TAN Method 380-Nessler, Hach DR/2010). Morning tank DO averaged $83.3 \pm 2.9 \%( \pm \mathrm{SD})$ saturation or $6.3 \pm 0.2 \mathrm{ppm}$, while average postprandial DO was $75.2 \pm 3.9 \%$ saturation or $5.7 \pm 0.3 \mathrm{ppm}$ with no discernible patterns with respect to treatment or time. The lowest postprandial DO recorded during the trial was 59\% saturation or $4.4 \mathrm{ppm}$ on one occasion. Culture system $\mathrm{pH}$ ranged from 8.0 to 8.2 and morning TAN concentrations ranged from 0.20 to $0.30 \mathrm{ppm}$ with little variation. Postprandial TAN gradually increased over time from $0.27 \pm 0.14 \mathrm{ppm}$ at the beginning of the trial to $0.71 \pm 0.26 \mathrm{ppm}$ at the end of the trial. The highest postprandial TAN recorded during the trial was $1.36 \mathrm{ppm}$ or $0.16 \mathrm{ppm}$ unionized ammonia.

\subsection{Diets and feeding}

The six commercial-grade diets (Table 1) were formulated on an ideal protein basis to contain one of three digestible protein (DP) levels $(33,40,47 \%)$ and one of two lipid levels ( $10 \%$ or $18 \%)$. Apparent digestibility coefficients (ADCs) of gross nutrients and amino acid availability in the protein sources were determined in prior trials in our lab (Barrows et al., 2011) and used to formulate the test diets. Digestible protein in the diets was provided in a fixed ratio among sources in 
order to minimize ingredient effects. Fish oil from all sources was held constant at $5 \%$ in the diets in order to meet minimum essential fatty acid requirements, while the remainder of dietary lipid was provided by poultry fat. Both the menhaden fish oil and poultry fat were obtained stabilized with ethoxyquin. The ideal protein model for formulation was the amino acid pattern of hybrid striped bass muscle (Gaylord and Rawles, 2005) at each dietary level of DP. Diets were supplemented with the first two limiting amino acids (Met, Lys) up to the ideal level (Table 2).

Diets were manufactured with commercial methods using a twinscrew cooking extruder (DNDL-44, Buhler AG, Uzwil, Switzerland) at the Bozeman Fish Technology Center, Bozeman, Montana. Diet mash was exposed to an average of $114{ }^{\circ} \mathrm{C}$ for 18 -s in five barrel sections and the last section was water cooled to an average temperature of $83^{\circ} \mathrm{C}$. Pressure at the die head varied from 300 to 580 psi depending on the diet formulation. The $3.0-\mathrm{mm}$ pellets were then dried in a pulse bed drier (Buhler AG) for $25 \mathrm{~min}$ at $102{ }^{\circ} \mathrm{C}$ and cooled at ambient air temperatures for final moisture levels of $<10 \%$. Fish oil was top-dressed using vacuum coating (A.J Flauer Mixing, Ontario, Canada) after the pellets were cooled. Diets were bagged and shipped to the HKDSNARC where they were stored in a temperature controlled $\left(18-20^{\circ} \mathrm{C}\right)$ feed room until use.

Each replicate tank of fish was assigned an individually weighed bucket of feed with appropriate diet in order to calculate daily intake. Fish were fed once daily from 1000-1200 h. Tanks receiving the full fed ration were fed to satiation, where satiation was defined as no further feeding activity for five consecutive minutes. Any pellets left in a tank after satiation was achieved were collected and used to calculate actual feed consumption. Fish in full fed ration treatments were typically sated within one hour. Mean feed consumption for each DP $\mathrm{x}$ lipid $\mathrm{x}$ full fed treatment group were calculated daily and

Table 1

Formulations ( $\mathrm{g} / \mathrm{kg}$ dry weight) and composition (as-is) of extruded diets fed to hybrid striped bass cultured at elevated temperature $\left(30.5 \pm 0.5^{\circ} \mathrm{C}\right)$.

\begin{tabular}{|c|c|c|c|c|c|c|}
\hline \multirow[t]{2}{*}{ Ingredient } & \multicolumn{6}{|c|}{ Digestible protein/ dietary lipid level } \\
\hline & $47 / 18$ & $47 / 10$ & $40 / 18$ & $40 / 10$ & $33 / 18$ & $33 / 10$ \\
\hline Menhaden fish meal - Select ${ }^{\mathrm{TM} 1}$ & 199.6 & 199.3 & 169.4 & 169.4 & 139.1 & 138.7 \\
\hline Soybean meal ${ }^{2}$ & 271.5 & 271.0 & 230.3 & 230.3 & 189.1 & 188.6 \\
\hline $\begin{array}{l}\text { Poultry by-product meal - } \\
\text { pet-food grade }{ }^{3}\end{array}$ & 218.6 & 218.2 & 185.4 & 185.4 & 152.3 & 151.9 \\
\hline Blood meal, spray dried poultry ${ }^{3}$ & 43.8 & 43.8 & 37.2 & 37.2 & 30.5 & 30.5 \\
\hline Feather meal $^{3}$ & 56.3 & 56.2 & 47.7 & 47.7 & 39.2 & 39.1 \\
\hline Wheat starch ${ }^{4}$ & 39.4 & 120.5 & 144.9 & 224.8 & 250.6 & 330.9 \\
\hline Menhaden fish oil ${ }^{5}$ & 34.9 & 34.9 & 37.2 & 37.2 & 39.5 & 39.5 \\
\hline Poultry fat ${ }^{3}$ & 91.3 & 11.4 & 97.2 & 17.3 & 103.1 & 23.1 \\
\hline Vitamin premix ${ }^{6}$ & 10.0 & 10.0 & 10.0 & 10.0 & 10.0 & 10.0 \\
\hline Choline chloride $50 \%$ & 6.0 & 6.0 & 6.0 & 6.0 & 6.0 & 6.0 \\
\hline Mineral $\operatorname{mix}^{7}$ & 1.0 & 1.0 & 1.0 & 1.0 & 1.0 & 1.0 \\
\hline Dicalcium phosphate & 0.0 & 0.0 & 10.0 & 10.0 & 20.0 & 20.0 \\
\hline DL-methionine & 7.8 & 7.8 & 6.7 & 6.7 & 5.5 & 5.6 \\
\hline Lysine $\mathrm{HCl}$ & 19.8 & 19.9 & 17.0 & 17.0 & 14.1 & 14.1 \\
\hline \multicolumn{7}{|l|}{ Analyzed Composition (as-is) } \\
\hline Crude protein ( $\mathrm{N} \times 6.25), \mathrm{g} / \mathrm{kg}$ & 543.0 & 544.6 & 469.1 & 464.2 & 387.0 & 385.9 \\
\hline Crude fat, $\mathrm{g} / \mathrm{kg}$ & 158.6 & 88.9 & 161.3 & 88.8 & 157.9 & 90.9 \\
\hline Gross energy, MJ/kg & 21.7 & 20.5 & 21.4 & 19.7 & 21.2 & 19.6 \\
\hline Moisture, g/kg & 20.5 & 17.6 & 23.2 & 20.9 & 20.5 & 17.4 \\
\hline Phosphorus, g/kg & 13.5 & 12.9 & 13.3 & 12.6 & 12.8 & 12.7 \\
\hline
\end{tabular}

\footnotetext{
1 Omega Protein, Inc., Houston, TX.

2 ADM Inc., Decatur, IL; $480 \mathrm{~g} / \mathrm{kg}$ protein.

3 Tyson Foods, Inc., Sedalia, MO.

4 Manildra Milling, Shawnee Mission, KS; $4 \mathrm{~g} / \mathrm{kg}$ protein.

${ }^{5}$ Omega Protein, Inc., Reedville, VA.

${ }^{6}$ Contributed, per kg of diet: vitamin A, $9650 \mathrm{IU}$; vitamin D, $6600 \mathrm{IU}$; vitamin E, $132 \mathrm{IU}$; vitamin K3, $1.1 \mathrm{mg}$; thiamin mononitrate, $9.1 \mathrm{mg}$; riboflavin $9.6 \mathrm{mg}$,; pyridoxine hydrochloride, $13.7 \mathrm{mg}$; pantothenate, DL-calcium, $46.5 \mathrm{mg}$; cyancobalamin, $0.03 \mathrm{mg}$; nicotinic acid, $21.8 \mathrm{mg}$; biotin, $0.34 \mathrm{mg}$; folic acid, $2.5 \mathrm{mg}$; inositol, $600 \mathrm{mg}$.

7 Contributed, $\mathrm{mg} / \mathrm{kg}$ of diet: zinc 40; manganese, 13; iodine, 5; copper, 9.
}

Table 2

Analyzed amino acid composition ( $\mathrm{g} / \mathrm{kg}$ dry weight) of hybrid striped bass muscle and experimental diets ${ }^{1}$

\begin{tabular}{clllllllll}
\hline & Muscle $^{2}$ & Diet & Diet & Muscle $^{2}$ & Diet & Diet & Muscle $^{2}$ & Diet & Diet \\
\hline Amino & $470 \mathrm{~g}$ & $47 /$ & $47 /$ & $400 \mathrm{~g}$ & $40 /$ & $40 /$ & $330 \mathrm{~g}$ & $33 /$ & $33 /$ \\
acid & & 18 & 10 & & 18 & 10 & & 18 & 10 \\
Ala & 24.3 & 33.2 & 32.9 & 20.7 & 27.6 & 27.6 & 17.0 & 23.1 & 23.1 \\
Arg & 48.4 & 46.3 & 44.1 & 41.2 & 41.8 & 38.9 & 34.0 & 34.9 & 34.6 \\
Asx & 52.0 & 50.5 & 50.5 & 44.3 & 42.5 & 42.4 & 36.5 & 35.5 & 35.1 \\
Cys & 6.1 & 8.5 & 8.3 & 5.2 & 7.1 & 7.0 & 4.3 & 5.6 & 5.7 \\
Glx & 67.5 & 72.7 & 72.0 & 57.5 & 61.0 & 61.5 & 47.4 & 50.9 & 50.9 \\
Gly & 28.6 & 38.4 & 37.8 & 24.4 & 32.0 & 31.8 & 20.1 & 26.8 & 26.8 \\
His & 15.3 & 12.9 & 12.8 & 13.1 & 11.1 & 10.8 & 10.8 & 9.3 & 9.0 \\
Ile & 22.0 & 24.3 & 23.9 & 18.7 & 20.4 & 20.2 & 15.5 & 17.0 & 17.2 \\
Leu & 35.5 & 42.1 & 41.5 & 30.2 & 35.3 & 35.0 & 24.9 & 29.4 & 29.2 \\
Lys & 40.7 & 53.1 & 53.3 & 34.7 & 45.2 & 44.7 & 28.6 & 37.1 & 37.5 \\
Met & 15.5 & 21.9 & 21.7 & 13.2 & 18.8 & 18.8 & 10.9 & 15.3 & 15.2 \\
Phe & 19.8 & 24.0 & 23.9 & 16.8 & 20.5 & 20.2 & 13.9 & 17.1 & 16.8 \\
Ser & 26.2 & 23.3 & 23.8 & 22.3 & 18.7 & 19.2 & 18.4 & 15.3 & 15.0 \\
Thr & 27.3 & 20.8 & 20.8 & 23.3 & 17.2 & 17.3 & 19.2 & 14.2 & 14.0 \\
Tyr & 17.9 & 15.1 & 14.9 & 15.2 & 12.4 & 12.3 & 12.5 & 10.1 & 9.8 \\
Val & 24.7 & 31.0 & 30.6 & 21.0 & 25.8 & 25.6 & 17.3 & 21.7 & 21.9 \\
\hline
\end{tabular}

1 Diet designations are \% digestible protein / \% dietary lipid level.

2 Amino acid composition of $470 \mathrm{~g}, 400 \mathrm{~g}$, or $330 \mathrm{~g}$ hybrid striped bass muscle protein.

multiplied by 0.8 to yield that day's feed amount for corresponding groups in the restricted ration treatment. All three tanks in a particular restricted ration group were offered $80 \%$ of the corresponding mean full fed ration intake irrespective of tank biomass. Any pellets left in a restricted ration tank after five consecutive minutes of no further feeding were also collected and used to calculate actual consumption. The weight of uneaten feed for each tank was estimated by counting the total number of uneaten (wet) pellets and multiplying by pellet number:weight ratios determined in multiple dry samples of each diet.

\subsection{Fish and tissue sampling}

Fish were individually weighed on three occasions: at the start of the experiment, on days 38-40, and at the end of experiment (days 117-119). Prior to the initial and second weighings, feed was withheld for $36 \mathrm{~h}$, the culture system temperature was lowered $\left(-0.2^{\circ} \mathrm{C} \mathrm{h}^{-1}\right)$ to $24{ }^{\circ} \mathrm{C}$ and fish were anesthetized with clove oil to facilitate handling and reduce stress. During the second weighing, the number of fish in each tank was halved (10) by random stratified sampling based on weights of individually tagged fish in order to reduce potential crowding and water quality issues. Water temperature was subsequently returned to the target temperature $\left(30.5^{\circ} \mathrm{C}\right)$ within 14 days $\left(+0.5^{\circ} \mathrm{C} \mathrm{d}^{-1}\right)$ after weighing, where it remained until the end of the trial. Animal care and experimental protocols used in this study were approved by the Harry K. Dupree Stuttgart National Aquaculture Research Center Institutional Animal Care and Use Committee and conformed to Agricultural Research Service Policies and Procedures 130.4 and 635.1.

At the end of the trial, fish were fasted for $22-24 \mathrm{~h}$ and half of the fish in each tank (5) were randomly selected for the determination of whole body composition and nutrient retention while the remaining fish (5) were dissected for analysis of body composition indices that included hepatosomatic index (HSI), intraperitoneal fat (IPF) ratio, and muscle ratio (MR). Whole bodies of initial fish prior to the start of the trial and from each tank at the end of the trial were roughground with a single pass through an industrial meat grinder (Hobart Inc., Troy, $\mathrm{OH}$ ) fitted with a $24 \mathrm{~mm}$ grinder plate then stored at $-20{ }^{\circ} \mathrm{C}$ until further processing. Rough-ground samples were subsequently passed two additional times through a $6 \mathrm{~mm}$ grinder plate and collected in a chilled stainless steel bowl to produce whole 
body homogenates. Whole body homogenates were pooled for each tank, thoroughly mixed, and three 100 -g aliquots were packed into plastic trays and lyophilized (FreeZone ${ }^{\circledR}$ Triad ${ }^{\mathrm{TM}}$ freeze-drier, Model 7400030, Labconco, Inc., Kansas City, MO). Lyophilized samples were ground in a stainless steel laboratory blender to produce a uniform powder for analysis. Three aliquots of pooled, whole body sample from each tank were analyzed and averaged to obtain one representative value per tank.

\subsection{Diet and tissue chemical analyses}

Proximate composition of diets and fish were determined according to standard methods (AOAC, 2005). Briefly, moisture was determined after drying in a convection oven (Isotemp $750 \mathrm{~F}$, Fisher Scientific, Hanover Park, IL). Protein ( $\mathrm{N}$ x 6.25) was determined by the Dumas method using a LECO nitrogen analyzer (FP428, LECO Corporation, St. Joseph, MI). Total energy was determined by isoperibol bomb calorimetry (Parr1281, Parr Instrument Company Inc., Moline, IL). Lipid was determined by gravimetric quantification following petroleum ether extraction (AOCS, 2009; Method AM 5-04) in an ANKOM XT15 lipid extractor (ANKOM Technology, Inc., Macedon, NY). Diet and tissue samples were also subjected to basic hydrolysis according to Rayner (1985) without the addition of thioglycollic acid followed by amino acid analysis according to the methods of Henderson et al. (2006) on a highperformance liquid chromatography system (HP1100; Agilent Technologies, Wilmington, DE) equipped with a reversed-phase analytical column (Agilent Zorbax AAA $3.0 \times 150 \mathrm{~mm}, 3.5 \mu \mathrm{m}$ ) and fluorescence detector (Hewlett-Packard G1321-A). Protein, energy and amino acid retention efficiencies were estimated as:

Protein, energy, or amino acid retention efficiency $(R E)=$ (protein, energy, or amino gain $\times 100) /($ protein, energy, or amino acid fed $)$.

\subsection{Nitrogen and phosphorus excretion}

Eight days before termination of the diet study, all fish were fasted for $92 \mathrm{~h}$ and then fed a single meal of their corresponding diet offered at the full fed or restricted ration. Postprandial ammonia (total ammonianitrogen) and phosphorus (soluble reactive phosphorus) excretion were measured for fish in all treatment tanks over a 24 -h period. The full fed ration rate for the meal was the average satiate feed consumption during the $7 \mathrm{~d}$ period prior to fasting for each replicate tank of each diet. Fish in restricted ration treatment tanks were fed $80 \%$ of the 7-d mean satiate feed consumption of their assigned diet; all replicate tanks within a particular diet received the same amount of feed. Feeding response was observed and any uneaten feed was retrieved and subtracted from the weight of feed offered as previously described.

One day prior to ammonia sampling, water flow was uniformly decreased from 2.5 to $2 \mathrm{~L} / \mathrm{min}$ in all tanks in order to insure that levels of TAN during the excretion trial were well within analytical capabilities. Water samples were collected at mid-water column depth in the center of each tank and from one randomly selected tank inlet just prior to feeding and at 2, 4, 6, 8, 10, 12, 16, 20, and $24 \mathrm{~h}$ after feeding. At each sampling, about $30 \mathrm{~mL}$ of water from each tank and the inlet were filtered sequentially through a 1- $\mu \mathrm{m}$ filter (Acrodisc glass fiber filter) and a $0.2-\mu \mathrm{m}$ filter (Acrodisc ion chromatography Supor [PES] membrane filter) into a labeled $50-\mathrm{mL}$ polypropylene centrifuge tube and refrigerated until analysis. Ammonia analysis was initiated immediately following sample collection and phosphorus analysis was initiated within $24 \mathrm{~h}$ of collection. Total ammonia-nitrogen (TAN) was analyzed fluorometrically using the $o$-phthaldialdehyde method in a flow injection analysis system (Genfa and Dasgupta, 1989). Soluble reactive phosphorus (SRP; ascorbic acid method) was analyzed using flow injection analysis according to manufacturer instructions (FIAlab 2500, FIAlab Instruments, Bellevue, WA).
Ammonia and phosphorus excretion were calculated for each time period using the equation given by Thomas and Piedrahita (1998):

$r p=\frac{Q e C e}{V}+\frac{C e(t+\Delta t)-C e(t)}{\Delta t}-\frac{Q i C i}{V}$,

where $r_{p}$ is the ammonia-nitrogen or phosphate-phosphorus production rate $(\mathrm{mg} / \mathrm{L} / \mathrm{h})$ over time interval, $p$ (e.g., $0-2 \mathrm{~h}), Q_{i}$ and $Q_{e}$ are the influent and effluent water flow rates $(\mathrm{L} / \mathrm{h})$, respectively, $C_{i}$ and $C_{e}$ are the influent and effluent $\mathrm{NH}_{4}-\mathrm{N}$ or $\mathrm{PO}_{4}-\mathrm{P}$ concentrations $(\mathrm{mg} / \mathrm{L})$, respectively, $\mathrm{C}_{e(t)}$ is the effluent $\mathrm{NH}_{4}-\mathrm{N}$ or $\mathrm{PO}_{4}-\mathrm{P}$ concentration $(\mathrm{mg} / \mathrm{L})$ at time $t, C_{e(t+\Delta t)}$ is the effluent $\mathrm{NH}_{4}-\mathrm{N}$ or $\mathrm{PO}_{4}-\mathrm{P}$ concentration $(\mathrm{mg} / \mathrm{L})$ at time $(t+\Delta t), V$ is the tank volume (L), and $t$ is time (h). Total daily $\mathrm{NH}_{4}-\mathrm{N}$ and $\mathrm{PO}_{4}-\mathrm{P}$ production was the summation over the 24 -h period of each time interval's production. Flow rate at each tank inlet was measured at three different times during the 24 -h period and the mean was used for all calculations. At the conclusion of the ammonia trial, flow rate was increased to its original level $(2.5 \mathrm{~L} / \mathrm{min})$ and fish were fed an additional three days prior to harvest. The dry matter $\mathrm{N}$ and $\mathrm{P}$ contents of feed fed in the ammonia trial were used to calculate excretion rates per unit weight of $\mathrm{N}$ or $\mathrm{P}$ fed and the total weight of fish harvested/tank was used to calculate excretion rates per unit of fish body weight (BW). The amount of feed consumed at the beginning of the excretion trial averaged $1.12 \%$ of BW among full fed ration tanks and $0.96 \%$ among restricted ration tanks.

\subsection{Statistical analysis}

Fish production data, tissue composition, and nutrient retention efficiencies were analyzed by mixed model factorial analysis of variance (ANOVA) using PROC MIXED in SAS version 9.1.3 (SAS Institute, Inc., Cary, NC). Body compositional indices data were analyzed by mixed model factorial ANOVA with repeated measures (compound symmetry covariance structure). Differences among least squares means were evaluated using the DIFF option with the Bonferroni adjustment of P values in SAS in order to apply one of the most conservative means comparisons for reducing experiment-wise error rate. Percent data were log transformed prior to data analysis (Sokal and Rohlf, 1995).

Daily TAN and SRP excretion data were analyzed using the mixed models analysis of variance, linear regression analysis, and general linear models procedures of SAS version 9.1.3. Ammonia data from one replicate tank of the full fed 47/18 diet treatment was excluded from the analyses because of poor feeding response by fish in that tank and subsequent difficulty in retrieving all of the uneaten feed. Differences among least squares treatment means in the mixed models analysis were evaluated using the DIFF option with the Bonferroni adjustment of $\mathrm{P}$ values in SAS. Differences among any responses were declared significant at $P<0.05$.

\section{Results}

\subsection{Growth, feed performance, and condition indices}

Mean final fish weights and weight gains of hybrid striped bass reared at $30.5{ }^{\circ} \mathrm{C}$ for 116 days ranged from $275 \mathrm{~g}$ to $434 \mathrm{~g}$ with corresponding gains of $266 \%$ to $475 \%$ (Table 3 ). Final weight and weight gains increased with increasing ration, dietary lipid, and DP level without interaction. However at the highest weight gains, which were observed when diets containing $18 \%$ lipid were fed to satiation, the difference in final average weight between $40 \%$ and 47\%DP, was less than $10 \mathrm{~g}$ ( $434 \mathrm{~g}$ vs. $425 \mathrm{~g}$, respectively). On the other hand, average weight of fish fed 33\% DP was more than $90 \mathrm{~g}$ less (334 g) than that of fish fed $40 \%$ DP.

Greater total feed consumption was also correlated with higher feeding rate, increasing dietary lipid, and increasing DP. However, a 
highly significant dietary lipid $\mathrm{x}$ DP interaction $(P<0.001)$ was detected for total feed consumption (Table 3 ). At 18\% dietary lipid, total intakes among DP levels were distinctly different and increased with increasing DP. At 10\% dietary lipid, however, fish fed diets containing $47 \%$ or $40 \%$ DP consumed similar amounts of feed which were greater than that of fish fed 33\% DP (Table 6).

A distinctly different pattern was observed when feed consumption was expressed as average daily intake (ADI) with respect to body weight. ADI differed by ration and DP level with a highly significant $(P<0.001)$ dietary lipid $x$ DP interaction (Table 3$)$. In addition to ADI increasing with the higher feeding rate (Full fed), at 18\% dietary lipid fish fed $40 \%$ DP consumed less as a percent of body weight per day than fish fed either $33 \%$ or $47 \%$ DP, while fish fed the $47 \%$ DP diets expressed the highest ADI (Table 6). At 10\% dietary lipid, however, there were no significant differences in ADI among DP levels.

Significant main effects on feed conversion ratio (FCR) were observed with a highly significant $(P<0.001)$ dietary lipid $\mathrm{x}$ DP interaction (Table 3). FCR improved with restricted feeding and higher (18\%) dietary fat. The highest FCRs were generally observed at 33\% DP while the lowest (best) FCRs were seen at 40\% DP and 18\% dietary lipid. However, at $18 \%$ dietary lipid, FCRs for the 33\% and 47\% DP diets were similar but greater than those at $40 \%$ DP; whereas, FCRs for the $40 \%$ and $47 \%$ DP diets were similar at $10 \%$ dietary lipid but lower than those observed for the 33/10 diet (Table 6).

Dietary lipid and DP level significantly altered HSI with significant ration $\mathrm{x}$ DP $(P=0.005)$ and lipid $\mathrm{x}$ DP $(P<0.001)$ interactions (Table 3$)$.
Generally, HSI decreased with increasing DP with differences in HSI among DP levels being more profound at 18\% dietary lipid than at 10\% dietary lipid (Table 6). Additionally, ration level did not significantly change HSI at 33\% and $40 \%$ DP; whereas, at 47\% DP livers from full fed fish were significantly larger than those from feed restricted fish (Table 6).

IPF deposition also significantly changed in response to main effects with significant lipid x DP $(P=0.004)$ interaction (Table 3). IPF tended to be lowest at 47\% DP and 18\% dietary lipid and higher in fish fed the 33/18 and 40/18 diets; however, at 10\% dietary lipid IPF among DP levels did not significantly differ (Table 6).

Muscle ratio minimally changed (51.3\% to $54.2 \%$ ) in response to dietary lipid and DP level (Table 3). Fish fed the 10\% lipid diets exhibited slightly higher muscle ratio than those fed $18 \%$ dietary lipid, while muscle ratio increased with increasing dietary protein. A significant ration $\mathrm{x}$ lipid interaction $(P=0.02)$ was detected for muscle ratio with no discernible pattern (Table 3 ).

\subsection{Body composition and nutrient retention}

Average whole body crude protein content ranged from $17.3 \%$ to $19.6 \%$ and was unaffected by DP level and only minimally altered by dietary lipid (Table 4). Whole body crude protein averaged slightly higher in fish fed lower fat (18.9\% vs. 18.0\%). However, a significant ration $\mathrm{x}$ lipid interaction $(P=0.015)$ was detected such that dietary lipid level had no effect on whole body protein when fish were full fed (Table 5 ). On the other hand, fish fed diets containing 10\% fat contained slightly more protein

Table 3

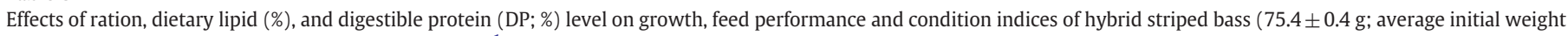
$\pm \mathrm{SD})$ cultured at elevated temperature $\left(30.5 \pm 0.5^{\circ} \mathrm{C}\right) .^{1}$

\begin{tabular}{|c|c|c|c|c|c|c|c|c|c|c|}
\hline \multirow{2}{*}{\multicolumn{3}{|c|}{ Dietary treatments }} & \multicolumn{8}{|c|}{ Response variable $^{3}$} \\
\hline & & & \multirow{2}{*}{$\begin{array}{l}\text { Final } \\
\text { weight }\end{array}$} & \multirow{2}{*}{$\begin{array}{l}\text { Weight } \\
\text { gain }\end{array}$} & \multicolumn{6}{|l|}{ Total } \\
\hline Ration $^{2}$ & Lipid & $\overline{\mathrm{DP}}$ & & & Feed & ADI & FCR & HSI & IPF & MR \\
\hline $\mathrm{F}$ & 10 & 33 & 310 & 312 & 4859 & 1.88 & 1.62 & 1.58 & 6.1 & 52.9 \\
\hline $\mathrm{F}$ & 10 & 40 & 382 & 406 & 5434 & 1.80 & 1.38 & 1.54 & 6.6 & 53.4 \\
\hline $\mathrm{F}$ & 10 & 47 & 422 & 461 & 5745 & 1.81 & 1.33 & 1.34 & 6.5 & 54.1 \\
\hline $\mathrm{F}$ & 18 & 33 & 334 & 344 & 5067 & 1.85 & 1.54 & 2.11 & 9.1 & 50.1 \\
\hline $\mathrm{F}$ & 18 & 40 & 425 & 463 & 5435 & 1.69 & 1.23 & 1.63 & 7.9 & 51.9 \\
\hline $\mathrm{F}$ & 18 & 47 & 434 & 475 & 6664 & 2.01 & 1.47 & 1.24 & 7.3 & 52.7 \\
\hline $\mathrm{R}$ & 10 & 33 & 275 & 266 & 3893 & 1.62 & 1.52 & 1.89 & 6.2 & 52.0 \\
\hline $\mathrm{R}$ & 10 & 40 & 346 & 357 & 4356 & 1.57 & 1.28 & 1.58 & 5.9 & 52.8 \\
\hline $\mathrm{R}$ & 10 & 47 & 382 & 406 & 4619 & 1.57 & 1.20 & 1.17 & 5.4 & 54.2 \\
\hline $\mathrm{R}$ & 18 & 33 & 326 & 332 & 4041 & 1.52 & 1.28 & 1.97 & 8.5 & 51.3 \\
\hline $\mathrm{R}$ & 18 & 40 & 371 & 390 & 4333 & 1.47 & 1.14 & 1.70 & 7.8 & 52.1 \\
\hline $\mathrm{R}$ & 18 & 47 & 398 & 428 & 5306 & 1.72 & 1.30 & 1.07 & 6.3 & 53.2 \\
\hline Pooled SEM & & & 12.5 & 16.1 & 106 & 0.03 & 0.03 & 0.08 & 0.28 & 0.40 \\
\hline \multicolumn{11}{|l|}{ Main effect means } \\
\hline $\mathrm{F}$ & & & $384 a$ & $410 a$ & $5534 a$ & $1.84 a$ & $1.42 \mathrm{a}$ & 1.57 & 7.3 & 52.5 \\
\hline \multirow[t]{6}{*}{$\mathrm{R}$} & & & $350 \mathrm{~b}$ & $363 b$ & $4424 b$ & $1.58 \mathrm{~b}$ & $1.29 \mathrm{~b}$ & 1.56 & 6.7 & 52.6 \\
\hline & 10 & & $353 b$ & $368 b$ & $4818 b$ & 1.71 & $1.39 a$ & 1.52 & 6.1 & $53.2 \mathrm{a}$ \\
\hline & 18 & & $381 a$ & $405 a$ & $5141 a$ & 1.71 & $1.33 b$ & 1.62 & 7.8 & $51.9 b$ \\
\hline & & 33 & $311 c$ & $313 c$ & 4465 & 1.72 & $1.49 a$ & $1.89 a$ & $7.5 a$ & $51.6 \mathrm{c}$ \\
\hline & & 40 & $381 b$ & $404 b$ & 4890 & 1.63 & $1.26 \mathrm{~b}$ & $1.61 b$ & $7.1 \mathrm{a}$ & $52.6 b$ \\
\hline & & 47 & 409a & $443 a$ & 5584 & 1.78 & $1.35 \mathrm{ab}$ & $1.21 \mathrm{c}$ & $6.4 \mathrm{~b}$ & $53.5 \mathrm{a}$ \\
\hline \multicolumn{11}{|l|}{ ANOVA Source, $\operatorname{Pr}>F$} \\
\hline Ration & & & $<0.001$ & $<0.001$ & $<0.001$ & $<0.001$ & $<0.001$ & 0.497 & 0.001 & 0.714 \\
\hline Lipid & & & $<0.001$ & $<0.001$ & $<0.001$ & 0.878 & 0.002 & 0.049 & $<0.001$ & $<0.001$ \\
\hline $\mathrm{DP}$ & & & $<0.001$ & $<0.001$ & $<0.001$ & $<0.001$ & $<0.001$ & $<0.001$ & $<0.001$ & $<0.001$ \\
\hline Ration x Lipid ${ }^{4}$ & & & 0.515 & 0.469 & 0.764 & 0.244 & 0.077 & 0.106 & 0.756 & 0.020 \\
\hline Ration $\mathrm{x} \mathrm{DP}^{4}$ & & & 0.559 & 0.582 & 0.998 & 0.371 & 0.311 & 0.005 & 0.061 & 0.632 \\
\hline Lipid x DP 4 & & & 0.169 & 0.112 & $<0.001$ & $<0.001$ & $<0.001$ & 0.001 & 0.004 & 0.378 \\
\hline Ration x Lipid $\mathrm{x}$ DP & & & 0.318 & 0.283 & 0.991 & 0.497 & 0.148 & 0.071 & 0.353 & 0.245 \\
\hline
\end{tabular}

\footnotetext{
1 Values are least squares means of $N=3$ replicate tanks of fish per treatment combination; Main effect least squares means in the same column with different letters are different $(P<0.05)$

2 Feed was offered at a full (F; satiation) or restricted ( $\mathrm{R} ; 80 \%$ of satiation) ration.

${ }^{3}$ Final mean fish weight ( $\mathrm{g}$ ) after 116 days; Weight gain $(\%)=$ (final weight - initial weight)*100 / initial weight; Total feed (g) consumed during trial; ADI: average daily intake

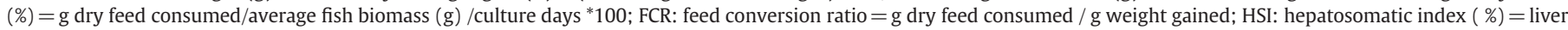
mass x 100 / fish mass; IPF: intraperitoneal fat $(\%)=$ intraperitoneal fat mass * 100 / fish mass; MR: muscle ratio (\%)= fillet with rib mass * 100 / fish mass.

4 In the case of significant two-way interaction see Table 6 for explanation.
} 
Table 4

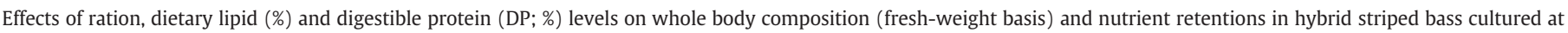
elevated temperature $\left(30.5 \pm 0.5^{\circ} \mathrm{C}\right) .{ }^{1}$.

\begin{tabular}{|c|c|c|c|c|c|c|c|c|c|c|c|c|c|c|c|c|c|}
\hline \multicolumn{3}{|c|}{ Dietary treatments } & \multicolumn{15}{|c|}{ Response variable ${ }^{3}$} \\
\hline Ration $^{2}$ & Lipid & DP & $\mathrm{CP}$ & Lipid & Energy & Moisture & PRE & ERE & $\operatorname{Arg}$ & His & Ile & Leu & Lys & Met & Phe & Thr & Val \\
\hline $\mathrm{F}$ & 10 & 33 & $19.1 \mathrm{a}$ & 10.5 & 2145 & 66.2 & $30.0 \mathrm{a}$ & $27.9 \mathrm{~b}$ & 19.5 & 26.8 & 28.0 & 27.3 & 24.6 & $28.0 \mathrm{a}$ & 26.1 & 31.0 & 25.3 \\
\hline $\mathrm{F}$ & 10 & 40 & $18.8 \mathrm{a}$ & 11.0 & 2144 & 65.7 & 28.7ab & $32.4 a$ & 20.6 & 27.3 & 28.1 & 27.3 & 24.8 & $25.6 \mathrm{ab}$ & 26.1 & 30.7 & 25.7 \\
\hline $\mathrm{F}$ & 10 & 47 & $18.5 a$ & 10.5 & 2033 & 66.5 & $25.1 b$ & 31.3ab & 19.6 & 23.7 & 25.7 & 24.4 & 22.3 & $22.4 b$ & 23.1 & 26.1 & 22.8 \\
\hline $\mathrm{F}$ & 18 & 33 & $17.7 \mathrm{~b}$ & 13.9 & 2321 & 63.8 & $29.2 \mathrm{a}$ & $29.2 \mathrm{ab}$ & 19.4 & 26.8 & 28.6 & 27.3 & 25.3 & $29.0 \mathrm{a}$ & 26.1 & 31.1 & 25.7 \\
\hline $\mathrm{F}$ & 18 & 40 & $19.0 \mathrm{a}$ & 13.3 & 2402 & 63.5 & $32.1 \mathrm{a}$ & $37.3 a$ & 19.9 & 28.0 & 29.5 & 28.5 & 25.7 & $28.8 \mathrm{a}$ & 27.6 & 32.7 & 27.0 \\
\hline $\mathrm{F}$ & 18 & 47 & 18.6ab & 11.5 & 2148 & 65.2 & $22.9 \mathrm{~b}$ & $27.7 b$ & 14.9 & 21.3 & 22.7 & 21.5 & 20.2 & $20.4 b$ & 20.7 & 23.6 & 20.3 \\
\hline $\mathrm{R}$ & 10 & 33 & $18.4 b$ & 10.0 & 1986 & 67.2 & $30.9 a$ & $27.4 \mathrm{~b}$ & 20.1 & 28.9 & 29.8 & 29.0 & 26.4 & $26.4 a$ & 27.8 & 32.2 & 26.7 \\
\hline $\mathrm{R}$ & 10 & 40 & 18.8ab & 9.5 & 2002 & 66.9 & $31.0 \mathrm{a}$ & $32.6 a$ & 21.1 & 28.8 & 30.4 & 29.1 & 26.7 & $26.1 \mathrm{a}$ & 27.9 & 30.7 & 27.8 \\
\hline $\mathrm{R}$ & 10 & 47 & $19.6 a$ & 9.4 & 2030 & 66.6 & $29.4 a$ & $34.7 \mathrm{a}$ & 18.6 & 25.0 & 26.4 & 25.3 & 23.2 & $26.7 a$ & 24.3 & 27.9 & 23.8 \\
\hline $\mathrm{R}$ & 18 & 33 & 17.3a & 13.0 & 2242 & 64.5 & $34.4 a$ & 34.0ab & 23.6 & 31.2 & 33.8 & 32.2 & 29.8 & $32.6 a$ & 30.7 & 33.9 & 30.6 \\
\hline $\mathrm{R}$ & 18 & 40 & $18.1 \mathrm{a}$ & 12.2 & 2198 & 65.4 & $33.0 \mathrm{a}$ & $36.9 \mathrm{a}$ & 23.3 & 30.9 & 33.2 & 31.9 & 29.2 & $29.5 a$ & 30.4 & 36.1 & 30.4 \\
\hline $\mathrm{R}$ & 18 & 47 & $17.3 a$ & 10.9 & 2081 & 66.5 & $24.6 \mathrm{~b}$ & $30.2 b$ & 18.3 & 22.7 & 23.6 & 22.7 & 21.4 & $21.9 \mathrm{~b}$ & 22.5 & 26.2 & 21.8 \\
\hline Pooled SEM & & & 0.36 & 0.34 & 51 & 0.38 & 0.82 & 0.92 & 1.07 & 1.14 & 1.32 & 1.19 & 1.09 & 1.00 & 1.07 & 1.27 & 1.11 \\
\hline \multicolumn{18}{|l|}{ Main effect means } \\
\hline $\mathrm{F}$ & & & 18.6 & $11.8 \mathrm{a}$ & $2199 a$ & $65.1 \mathrm{~b}$ & 28.0 & 31.0 & 19.0 & $25.6 \mathrm{~b}$ & $27.1 \mathrm{~b}$ & $26.0 \mathrm{~b}$ & $23.8 b$ & 25.7 & $24.9 b$ & $29.2 b$ & $24.5 b$ \\
\hline \multirow[t]{6}{*}{$\mathrm{R}$} & & & 18.3 & $10.8 \mathrm{~b}$ & 2090b & $66.2 \mathrm{a}$ & 30.5 & 32.6 & 20.8 & $27.9 a$ & $29.5 a$ & $28.4 a$ & $26.1 \mathrm{a}$ & 27.2 & $27.3 \mathrm{a}$ & $31.2 \mathrm{a}$ & $26.8 \mathrm{a}$ \\
\hline & 10 & & $18.9 \mathrm{a}$ & $10.1 \mathrm{~b}$ & $2057 b$ & $66.5 a$ & 29.2 & 31.0 & 19.9 & 26.7 & 28.1 & 27.0 & 24.7 & 25.9 & 25.9 & 29.8 & 25.4 \\
\hline & 18 & & $18.0 \mathrm{~b}$ & $12.4 \mathrm{a}$ & $2232 a$ & $64.8 \mathrm{~b}$ & 29.4 & 32.5 & 19.9 & 26.8 & 28.6 & 27.4 & 25.3 & 27.0 & 26.3 & 30.6 & 25.9 \\
\hline & & 33 & 18.1 & 11.8 & $2174 a$ & 65.4 & 31.1 & 29.6 & 20.7 & $28.4 a$ & $30.1 \mathrm{a}$ & $28.9 a$ & $26.5 a$ & 29.0 & $27.7 \mathrm{a}$ & $32.1 \mathrm{a}$ & $27.1 \mathrm{a}$ \\
\hline & & 40 & 18.7 & 11.5 & $2187 a$ & 65.4 & 31.2 & 34.8 & 21.2 & $28.7 \mathrm{a}$ & $30.3 a$ & $29.2 \mathrm{a}$ & $26.6 a$ & 27.5 & $28.0 \mathrm{a}$ & $32.5 \mathrm{a}$ & $27.7 \mathrm{a}$ \\
\hline & & 47 & 18.5 & 10.6 & $2073 b$ & 66.2 & 25.5 & 31.0 & 17.9 & $23.2 b$ & $24.6 b$ & $23.5 b$ & $21.8 \mathrm{~b}$ & 22.9 & $22.6 b$ & $26.0 \mathrm{~b}$ & $22.2 b$ \\
\hline \multicolumn{18}{|c|}{ ANOVA Source, $\operatorname{Pr}>F$} \\
\hline Ration & & & 0.108 & $<0.001$ & $<0.001$ & $<0.001$ & $<0.001$ & 0.002 & 0.008 & 0.004 & 0.008 & 0.005 & 0.003 & 0.010 & 0.002 & 0.017 & 0.002 \\
\hline Lipid & & & $<0.001$ & $<0.001$ & $<0.001$ & $<0.001$ & 0.855 & 0.010 & 0.703 & 0.834 & 0.776 & 0.935 & 0.559 & 0.142 & 0.727 & 0.456 & 0.636 \\
\hline $\mathrm{DP}$ & & & 0.132 & $<0.001$ & 0.006 & 0.007 & $<0.001$ & $<0.001$ & $<0.001$ & $<0.001$ & $<0.001$ & $<0.001$ & $<0.001$ & $<0.001$ & $<0.001$ & $<0.001$ & $<0.001$ \\
\hline Ration $\mathrm{x}$ Lipid $^{4}$ & & & 0.015 & 0.357 & 0.941 & 0.219 & 0.956 & 0.150 & 0.008 & 0.356 & 0.318 & 0.257 & 0.278 & 0.560 & 0.280 & 0.203 & 0.215 \\
\hline Ration x $\mathrm{DP}^{4}$ & & & 0.718 & 0.337 & 0.175 & 0.255 & 0.300 & 0.044 & 0.884 & 0.647 & 0.418 & 0.546 & 0.513 & 0.086 & 0.728 & 0.856 & 0.584 \\
\hline Lipid $x \mathrm{DP}^{4}$ & & & 0.142 & 0.003 & 0.103 & 0.009 & $<0.001$ & $<0.001$ & 0.026 & 0.050 & 0.016 & 0.017 & 0.036 & $<0.001$ & 0.031 & 0.014 & 0.016 \\
\hline Ration x Lipid & & & 0.050 & 0.612 & 0.467 & 0.498 & 0.030 & 0.036 & 0.601 & 0.889 & 0.816 & 0.836 & 0.890 & 0.037 & 0.840 & 0.886 & 0.798 \\
\hline
\end{tabular}

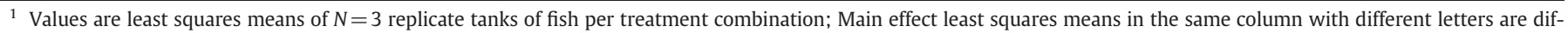
ferent $(P<0.05)$.

${ }^{2}$ Feed was offered at full (F; satiation) or restricted ( $R ; 80 \%$ of satiation) ration.

3 Whole body composition (fresh-weight basis) includes CP: crude protein (\%), Lipid (\%), Energy (kcal $/ \mathrm{kg}$ ), and Moisture (\%); PRE: protein retention efficiency = g protein gain $\mathrm{x}$

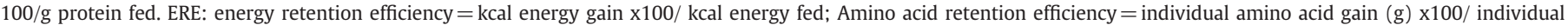
amino acid fed $(\mathrm{g})$.

${ }^{4}$ In the case of significant two-way interaction see Table 6 for explanation.

${ }^{5}$ In the case of significant three-way interaction, means among DP levels with different letters within a Ration $\mathrm{x}$ Lipid level are different $(P<0.05)$.

than fish fed diets containing $18 \%$ fat when feed was restricted to $80 \%$ of satiation. Fish fed diets containing $40 \%$ DP contained the numerically highest average whole body crude protein at $18.7 \%$ (Table 4 ). However, a significant three-way interaction was detected with no clear pattern in whole body protein among DP levels with respect to changes in ration $\mathrm{x}$ lipid treatment settings.

Whole body lipid concentrations were significantly altered by ration, dietary lipid level, and DP (Table 4). Fish fed to satiation contained more lipid than fish that were feed restricted, while whole body lipid increased with increasing dietary lipid, as well. Whole body lipid concentrations tended to be depressed by high (47\%) DP at 18\% dietary lipid, but a highly significant lipid $\mathrm{x}$ DP interaction $(P=0.003)$ was observed such that whole body lipid did not differ among DP levels at 10\% lipid (Table 5).

Whole body energy was significantly changed by main effects without interaction (Table 4). Whole body energy was greatest in fish fed diets containing either $33 \%$ or $40 \%$ DP and was depressed in fish fed diets containing $47 \%$ DP. Fish fed to satiation contained more energy than fish that were feed restricted. Similar to whole body lipid, whole body energy also increased with increasing dietary lipid level.

Main effects on whole body moisture were generally the inverse of those seen on whole body lipid (Table 4). Fish fed to satiation contained less moisture than fish that were feed restricted, while whole body moisture decreased with increasing dietary lipid. Whole body moisture increased with DP level at $18 \%$ dietary lipid, but a highly significant lipid $\mathrm{x}$ DP interaction $(P=0.009)$ was observed such that whole body moisture did not differ among DP levels at $10 \%$ lipid (Table 6).

The highest protein retentions (PRE) were observed at 18\% dietary lipid and $33 \%$ or $40 \%$ DP when feeding was restricted to $80 \%$ of satiation (Table 4). PRE was depressed by the highest DP level (47\%), however, significant lipid $\mathrm{x}$ DP $(P<0.001)$ and three-way $(P=0.03)$ interactions were found such that the magnitude of depression depended on ration $x$ lipid treatments (Table 6). Depression of PRE at 47\% DP and 18\% dietary lipid was about -10 percentage points regardless of ration, about -5 percentage points at $10 \%$ dietary lipid and full fed, and disappeared at low fat and restricted feeding.

Energy retention efficiency (ERE) tended to be highest at 40\% DP (Table 4). However, significant ration x DP, lipid x DP and three-way interactions were observed for ERE (Table 6). Both energy retention and the differences in ERE among DP levels were greatest in the presence of high dietary fat (18\%) and restricted feeding and much less profound at low dietary fat and satiation feeding. At $10 \%$ dietary fat, the lowest energy retentions were observed at $33 \%$ DP regardless of ration; whereas at $18 \%$ dietary fat, energy retentions of the $33 \%$ DP diet were intermediate to those of the 40/18 (highest) and 47/18 (lowest) diets. Also, restricted feeding tended to increase ERE of the 33\% and 47\% DP diets but had little effect on energy retention of the 40\% DP diets.

Amino acid retentions were highest at 33\% and 40\% DP and lowest at 47\% DP (Table 4). Significant dietary lipid x DP interactions were found for all amino acid retentions (Table 6) such that low dietary fat tended to 
Table 5

Effects of ration, dietary lipid (\%), and digestible protein (DP; \%) level on daily total ammonia-nitrogen (TAN) excretion of hybrid striped cultured at elevated temperature $\left(30.5 \pm 0.5^{\circ} \mathrm{C}\right) .^{1}$

\begin{tabular}{|c|c|c|c|c|c|}
\hline \multirow{2}{*}{\multicolumn{3}{|c|}{ Dietary treatments }} & \multicolumn{3}{|c|}{ Response variable ${ }^{3}$} \\
\hline & & & \multicolumn{3}{|l|}{ TAN } \\
\hline Ration $^{2}$ & Lipid & $\mathrm{DP}$ & $\mathrm{mg}$ & $\begin{array}{l}\mathrm{mg} / \mathrm{g} \text { fed } / \mathrm{kg} \\
\text { BW }\end{array}$ & $\begin{array}{l}\mathrm{mg} / \mathrm{g} \mathrm{N} \text { fed / } \mathrm{kg} \\
\mathrm{BW}\end{array}$ \\
\hline $\mathrm{F}$ & 10 & 33 & $534 \pm 65$ & $6.3 \pm 0.41$ & $104 \pm 5.7$ \\
\hline $\mathrm{F}$ & 10 & 40 & $990 \pm 65$ & $6.5 \pm 0.41$ & $90 \pm 5.7$ \\
\hline $\mathrm{F}$ & 10 & 47 & $1329 \pm 65$ & $6.8 \pm 0.41$ & $79 \pm 5.7$ \\
\hline $\mathrm{F}$ & 18 & 33 & $581 \pm 65$ & $5.1 \pm 0.41$ & $85 \pm 5.7$ \\
\hline $\mathrm{F}$ & 18 & 40 & $929 \pm 65$ & $5.6 \pm 0.41$ & $76 \pm 5.7$ \\
\hline $\mathrm{F}$ & 18 & 47 & $1360 \pm 80$ & $5.2 \pm 0.50$ & $61 \pm 6.9$ \\
\hline $\mathrm{R}$ & 10 & 33 & $548 \pm 65$ & $7.4 \pm 0.41$ & $123 \pm 5.7$ \\
\hline $\mathrm{R}$ & 10 & 40 & $933 \pm 65$ & $8.5 \pm 0.41$ & $117 \pm 5.7$ \\
\hline $\mathrm{R}$ & 10 & 47 & $1304 \pm 65$ & $8.9 \pm 0.41$ & $104 \pm 5.7$ \\
\hline $\mathrm{R}$ & 18 & 33 & $538 \pm 65$ & $6.1 \pm 0.41$ & $101 \pm 5.7$ \\
\hline $\mathrm{R}$ & 18 & 40 & $834 \pm 65$ & $7.8 \pm 0.41$ & $107 \pm 5.7$ \\
\hline $\mathrm{R}$ & 18 & 47 & $885 \pm 65$ & $5.4 \pm 0.41$ & $63 \pm 5.7$ \\
\hline
\end{tabular}

Main effect means

$\mathrm{F}$

$\mathrm{R}$

$\begin{array}{rrrl} & & 954 \pm 28 \mathrm{a} & 5.9 \pm 0.18 \mathrm{~b} \\ & & 840 \pm 27 \mathrm{~b} & 7.4 \pm 0.17 \mathrm{a} \\ 10 & & 940 \pm 27 & 7.4 \pm 0.17 \mathrm{a} \\ 18 & & 854 \pm 28 & 5.9 \pm 0.18 \mathrm{~b} \\ & 33 & 550 \pm 33 \mathrm{c} & 6.2 \pm 0.21 \\ & 40 & 921 \pm 33 \mathrm{~b} & 7.1 \pm 0.21 \\ & 47 & 1220 \pm 35 \mathrm{a} & 6.6 \pm 0.22\end{array}$

$\begin{array}{lrrr}\text { NOVA Source, } \operatorname{Pr}>F & & & \\ \text { Ration } & 0.038 & <0.001 & <0.001 \\ \text { Lipid } & 0.089 & <0.001 & <0.001 \\ \text { DP } & <0.001 & 0.032 & <0.001 \\ \text { Ration x Lipid } & 0.077 & 0.468 & 0.468 \\ \text { Ration x DP } & 0.218 & 0.260 & 0.260 \\ \text { Lipid x DP } & 0.234 & 0.048 & 0.065 \\ \text { Ration x Lipid x } & 0.268 & 0.189 & 0.189\end{array}$

1 Values are least squares means ( + SE) of $N=2$ replicate tanks of fish for the full fed $47 / 18$ treatment and $N=3$ for all other treatment combinations. Main effect least squares means in the same column with different letters are different $(P<0.05)$.

${ }^{2}$ Feed was offered at full ( $F$; satiation) or restricted ( $R$; $80 \%$ of satiation) ration.

3 TAN: total ammonia-nitrogen $\left(\mathrm{NH}_{4}-\mathrm{N}\right)$ in $\mathrm{mg}, \mathrm{mg} / \mathrm{g}$ dry feed fed / $\mathrm{kg}$ body weight (BW), or $\mathrm{mg} / \mathrm{g}$ feed nitrogen $(\mathrm{N})$ fed / $\mathrm{kg}$ BW.

${ }^{4}$ In the case of significant two-way interaction see Table 6 for explanation.

reduce retentions and in some cases even eliminate differences (e.g., Arg) among DP levels. Additionally, three-way interaction was observed for Met retention $(P=0.037)$ such that differences in Met retention among DP levels began to appear when the low-fat diets were fed to satiation as opposed to $80 \%$ of satiation. On the other hand, the highly significant ration $\mathrm{x}$ lipid interaction $(P=0.008)$ observed for Arg retention meant there were no differences among DP levels at $10 \%$ fat regardless of ration, i.e., Arg retention at $10 \%$ fat and intermediate DP was not increased or partially mitigated by satiation feeding.

\subsection{Nitrogen and phosphorus excretion}

When unadjusted for the amount of feed fed or fish body weight (BW), the total ammonia nitrogen (mg) excreted over a 24-hr period was significantly different with respect to ration and DP level (Table 5). Total ammonia was higher at the higher ration and increased with increasing digestible protein level. Interestingly, total ammonia excreted by fish in the $10 \%$ dietary lipid treatments was numerically higher than that of fish in the $18 \%$ lipid treatments but did not differ statistically in this case.

Mean hourly ammonia excretion rate increased linearly, peaked at $6 \mathrm{~h}$ postprandial in all treatments, and then decreased gradually over the next $18 \mathrm{~h}$ (Fig. 1). Slopes of hourly ammonia excretion rate differed

\section{Table 6}

Two-way interactions of ration (Full fed; Restricted), dietary lipid (10\%; 18\%), and digestible protein (33\%; 40\%; 47\%) on selected responses of hybrid striped bass cultured at elevated temperature $\left(30.5 \pm 0.5^{\circ} \mathrm{C}\right)$.

\begin{tabular}{|c|c|c|}
\hline Response variable & Interaction(s) & $\begin{array}{l}\text { Differences among treatment } \\
\text { combinations }{ }^{1}\end{array}$ \\
\hline \multicolumn{3}{|c|}{ Feed performance and condition indices } \\
\hline Total feed & Lipid x DP & $\begin{array}{l}\text { 10\% lipid: } 33 \%<40 \%=47 \% \text { DP } \\
\text { 18\% lipid: } 33 \%<40 \%<47 \% \text { DP }\end{array}$ \\
\hline ADI & Lipid x DP & $\begin{array}{l}10 \% \text { lipid: } 33 \%=40 \%=47 \% \text { DP } \\
18 \% \text { lipid: } 40 \%<33 \%<47 \% \text { DP }\end{array}$ \\
\hline FCR & Lipid x DP & $\begin{array}{l}10 \% \text { lipid: } 33 \%>40 \%=47 \% \text { DP } \\
18 \% \text { lipid: } 40 \%<33 \%=47 \% \text { DP }\end{array}$ \\
\hline HSI & Ration x DP & $\begin{array}{l}33 \% \text { DP: Full fed }=\text { Restricted } \\
40 \% \text { DP: Full fed }=\text { Restricted } \\
\text { 47\% DP: Full fed }>\text { Restricted } \\
\text { 10\% lipid: } 33 \%=40 \%>47 \% \text { DP } \\
18 \% \text { lipid: } 33 \%>40 \%>47 \% \text { DP }\end{array}$ \\
\hline IPF & Lipid x DP & $\begin{array}{l}10 \% \text { lipid: } 33 \%=40 \%=47 \% \text { DP } \\
18 \% \text { lipid: } 33 \%=40 \%>47 \% \text { DP }\end{array}$ \\
\hline \multicolumn{3}{|l|}{ Whole body composition } \\
\hline Protein & Ration x Lipid & $\begin{array}{l}\text { Full fed: } 10 \%=18 \% \text { lipid } \\
\text { Restricted: } 10 \%>18 \% \text { lipid }\end{array}$ \\
\hline Lipid & Lipid x DP & $\begin{array}{l}10 \% \text { lipid: } 33 \%=40 \%=47 \% \text { DP } \\
18 \% \text { lipid: } 33 \%=40 \%>47 \% \text { DP }\end{array}$ \\
\hline Moisture & Lipid x DP & $\begin{array}{l}10 \% \text { lipid: } 33 \%=40 \%=47 \% \text { DP } \\
18 \% \text { lipid: } 33 \%=40 \%<47 \% \text { DP }\end{array}$ \\
\hline \multicolumn{3}{|l|}{ Retention efficiencies } \\
\hline Protein (PRE) & Lipid x DP & $\begin{array}{l}\text { 10\% lipid: interaction with Ration } \\
\text { 18\% lipid: } 33 \%=40 \%>47 \% \text { DP }\end{array}$ \\
\hline Energy (ERE) & Ration x DP & $\begin{array}{l}\text { 33\% DP: Full fed }<\text { Restricted } \\
40 \% \text { DP: Full fed }=\text { Restricted } \\
\text { 47\% DP: Full fed }<\text { Restricted } \\
\text { 10\% lipid: } 33 \%<40 \%=47 \% \text { DP } \\
18 \% \text { lipid: } 47 \%<33 \%<40 \% \text { DP }\end{array}$ \\
\hline $\operatorname{Arg}$ & $\begin{array}{l}\text { Ration x Lipid } \\
\text { Lipid x DP }\end{array}$ & $\begin{array}{l}10 \% \text { lipid: Full fed }=\text { Restricted } \\
\text { 18\% lipid: Full fed }<\text { Restricted } \\
10 \% \text { lipid: } 33 \%=40 \%=47 \% \text { DP } \\
18 \% \text { lipid: } 33 \%=40 \%>47 \% \text { DP }\end{array}$ \\
\hline Met & Lipid x DP & $\begin{array}{l}\text { 10\% lipid: interaction with Ration } \\
\text { 18\% lipid: } 33 \%=40 \%>47 \% \text { DP }\end{array}$ \\
\hline $\begin{array}{l}\text { His, Ile, Leu, Lys, } \\
\text { Phe, Thr, Val }\end{array}$ & Lipid x DP & $\begin{array}{l}10 \% \text { lipid: } 33 \%=40 \% \geq 47 \% \text { DP } \\
18 \% \text { lipid: } 33 \%=40 \%>47 \% \text { DP }\end{array}$ \\
\hline $\begin{array}{l}\text { TAN } \\
\text { (mg / g dry feed fed / kg BW) }\end{array}$ & Lipid x DP & $\begin{array}{l}10 \% \text { lipid: } 33 \%=40 \%=47 \% \text { DP } \\
18 \% \text { lipid: } 40 \%=33 \% \geq 47 \% \text { DP }\end{array}$ \\
\hline
\end{tabular}

1 Less than or equal to sign $(\leq)$ between adjacent main effects denotes statistical overlap, e.g., $33 \% \leq 40 \% \leq 47 \%$ DP is the same as denoting the differences among the corresponding digestible protein (DP) means as $33 \%$ b, $40 \%$ ab, $47 \%$ a.

significantly among DP levels during $0-6 \mathrm{~h}$ postprandial. The mean hourly increase in ammonia excretion rate was significantly greater for fish fed the $47 \%$ DP diets ( $1.95 \mathrm{mg} \mathrm{NH}_{4}-\mathrm{N} / \mathrm{kg} / \mathrm{h}$ ) compared to fish fed the $33 \% \mathrm{DP}$ diets $\left(1.30 \mathrm{mg} \mathrm{NH}_{4}-\mathrm{N} / \mathrm{kg} / \mathrm{h}\right.$ ) and intermediate for fish fed the 40\% DP diets (1.78 $\mathrm{mg} \mathrm{NH}_{4}-\mathrm{N} / \mathrm{kg} / \mathrm{h}$ ). Both dietary lipid and digestible protein content significantly affected decreasing (6-24 h) slopes of hourly ammonia excretion rate. Slope of the decreasing (6-24 h) ammonia excretion rate for fish fed the $10 \%$ lipid diets was $-0.72 \mathrm{mg} \mathrm{NH}_{4}-\mathrm{N} / \mathrm{kg} / \mathrm{h}$, which was significantly more negative than that of fish fed the $18 \%$ lipid diets $\left(-0.62 \mathrm{mg} \mathrm{NH}_{4}-\mathrm{N} / \mathrm{kg} / \mathrm{h}\right.$ ). Slopes of the decreasing ammonia excretion rate for fish fed the $33 \%$ and $40 \%$ DP diets were similar $(-0.59$ and $-0.61 \mathrm{mg} \mathrm{NH}_{4}-\mathrm{N} / \mathrm{kg} / \mathrm{h}$, respectively) and significantly lower than those of fish fed the $47 \%$ DP diets ( $-0.80 \mathrm{mg} \mathrm{NH}_{4}-\mathrm{N} / \mathrm{kg} / \mathrm{h}$ ). 

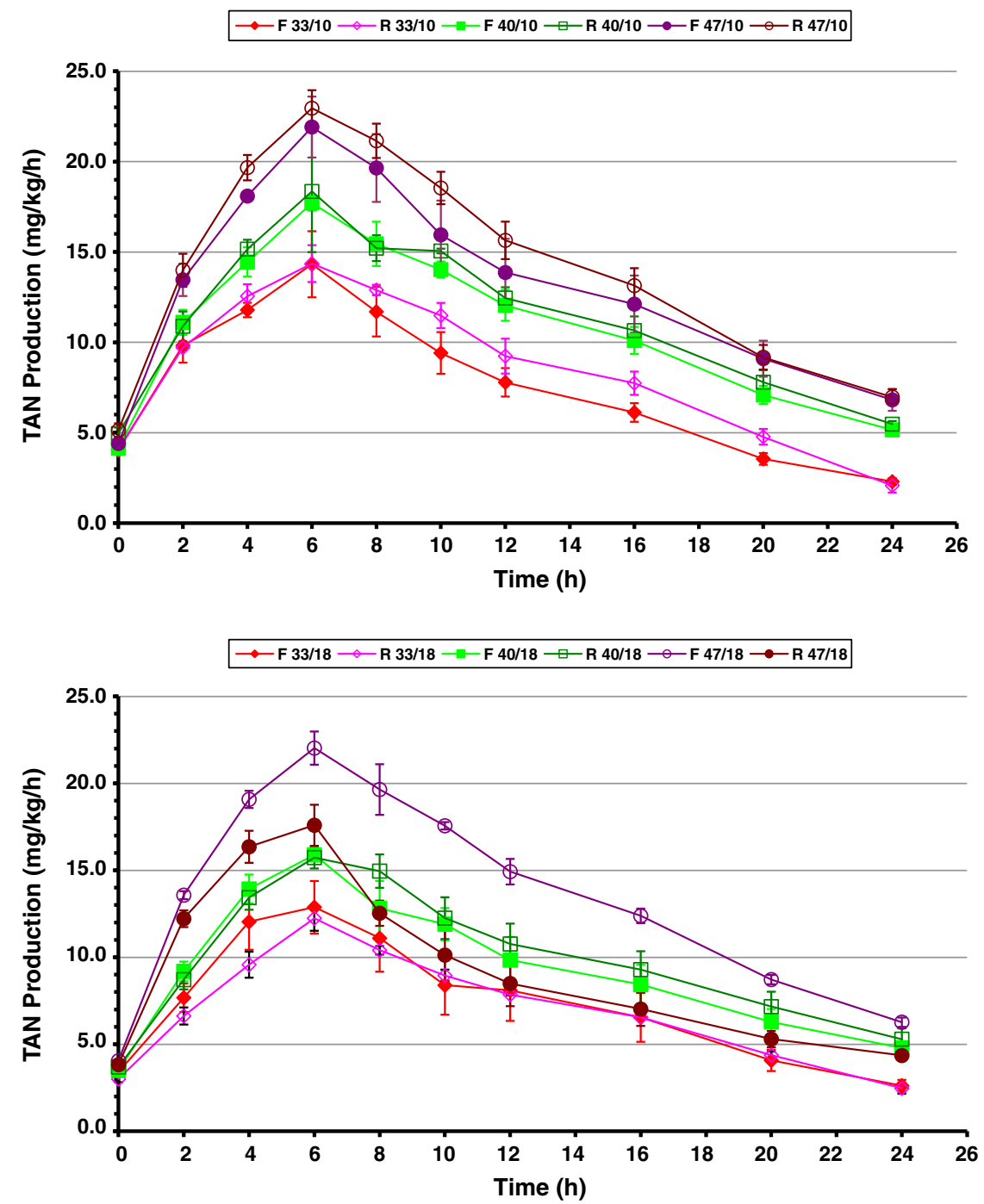

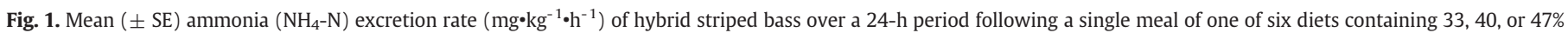

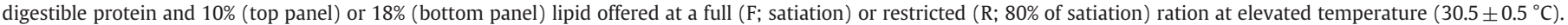

Ammonia excretion with respect to protein intake increased linearly and ration level did not significantly alter the slopes or intercepts of the regression lines. (Fig. 2). Daily protein intake accounted for $74 \%$ of the linear variation in total daily ammonia excretion by fish fed the full ration, and $42 \%$ of the linear variation observed for fish fed the restricted ration. Daily mean ammonia excretion also increased linearly with mean individual fish weight fed the full $\left(R^{2}=0.440\right)$ and restricted $\left(\mathrm{R}^{2}=0.303\right)$ ration.

Ammonia excretion expressed as g dry feed consumed per kg BW differed among main effects with a significant $(P=0.048)$ dietary lipid $\mathrm{x}$ DP interaction (Table 5). Fish that were feed restricted excreted significantly more ammonia than those that were full fed, while fish fed $10 \%$ dietary lipid excreted significantly more ammonia that those fed $18 \%$ dietary lipid. At $18 \%$ dietary lipid TAN excretion of the $33 \%$ and $40 \%$ diets was similar and higher than that of the $47 \%$ diet; however TAN excretion did not significantly differ among digestible protein level at $10 \%$ dietary lipid (Table 6).

A very different pattern emerges when ammonia excretion is expressed as $\mathrm{g}$ feed $\mathrm{N}$ consumed per $\mathrm{kg} \mathrm{BW}$. In this case, TAN excretion differed significantly by ration, dietary lipid, and DP levels without interaction (Table 5) and ranged from 61 to $123 \mathrm{mg}$ TAN $/ \mathrm{g} \mathrm{N}$ fed $/ \mathrm{kg}$ BW. Fish in the restricted feed treatment excreted significantly more feed $\mathrm{N}$ per $\mathrm{kg}$ BW than fish that were full fed, as did fish fed $10 \%$, as opposed to $18 \%$, dietary lipid. Additionally, ammonia excretion with respect to $\mathrm{N}$ consumed per BW decreased with increasing DP level in the diet.

Total excretion of dietary P did not differ significantly between ration or lipid levels, or among digestible protein levels; furthermore, no treatment interactions were detected. On average, 9.0\% of dietary P > was excreted and was not correlated with dietary $P$ intake. Phosphorus excretion per BW was not affected significantly by ration, dietary lipid, or DP level. Phosphorus excretion varied from 8.4-16.4 $\mathrm{mg} \mathrm{PO}_{4}-\mathrm{P} / \mathrm{kg} / \mathrm{d}$ among treatments and the grand mean was $11.6 \mathrm{mg} \mathrm{PO}_{4}-\mathrm{P} / \mathrm{kg} / \mathrm{d}$.

\section{Discussion}

Clearly, poorer feed performance, lower nutrient retentions and higher ammonia excretion point out the insufficiency of $10 \%$ dietary fat, as well as the excess of $47 \%$ digestible protein in the current study design for rearing hybrid striped bass at $30.5^{\circ} \mathrm{C}$. If we assume that $30.5^{\circ} \mathrm{C}$ is a fair estimate of the median summer water temperature in the Southern U.S., the question then becomes what trade-offs among production (i.e., weight gain, feed consumption, and feed conversion), nutrient retention and ammonia excretion are acceptable to maximize profitability, and at what feeding rate would either the $33 / 18$ or $40 / 18$ diet be optimal for culturing hybrid striped bass to $454 \mathrm{~g}(1 \mathrm{lb})$ during summer production. In order to answer this question and arrive at potential application of the 


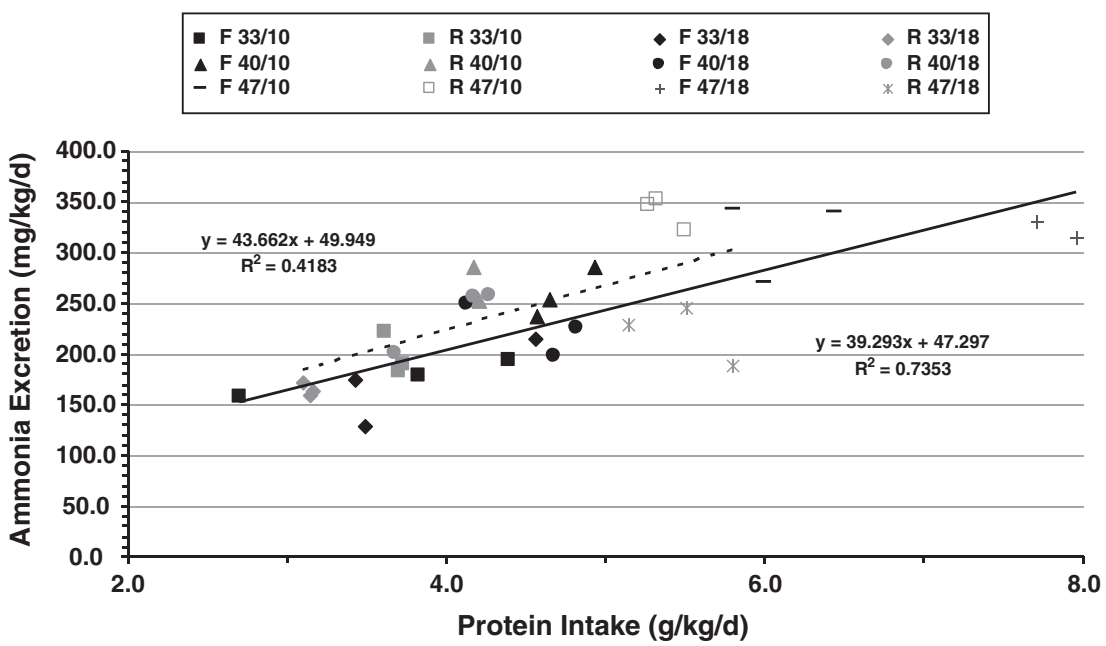

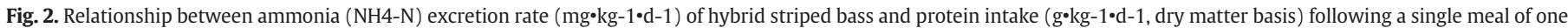

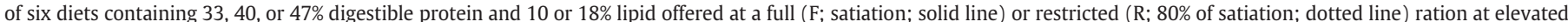
temperature $\left(30.5 \pm 0.5^{\circ} \mathrm{C}\right)$.

current results, the significant but generally consistent patterns of interactions among ration, dietary lipid and digestible protein levels in the current study must be considered.

At elevated temperature, $80 \%$ satiation feeding resulted in much lower final weight and weight gain but much higher ammonia excretion with respect to total feed fed, or nitrogen fed, per body weight (BW), regardless of digestible protein (DP) level. However, the 40/18 diet consistently outperformed the $33 / 18$ diet in better growth and lower ammonia excretion as a function of amount fed, or nitrogen fed per BW, and nearly equaled the growth attained by fish fed the $47 \%$ DP diets. Increasing ration to satiation at elevated temperature resulted in much greater improvements in weight gain, final weight and TAN excretion (down from 107 to $76 \mathrm{mg} / \mathrm{g} \mathrm{N}$ fed/ kg BW) of fish fed the 40/18 diet, as opposed to those fed the $33 / 18$ or $47 / 18$ diets. Weight gains in fish fed to satiation, for example, improved almost $19 \%$ in fish fed the $40 / 18$ diet, but only $11 \%$ in fish fed the $47 / 18$ diet, and less than $4 \%$ in those fed the $33 / 18$ diet.

Although ammonia production as a function of feed $\mathrm{N}$ and body weight was lowest in fish fed the 47/18 diet, several response characteristics detract from the efficacy of a $47 \%$ DP ( $54 \%$ CP) / $18 \%$ lipid diet for production of hybrid striped bass during summer scenarios. First, total ammonia production unadjusted for amount fed or body weight was markedly higher in fish fed the 47/18 diet. Secondly, the increasing and decreasing rates (slopes) of ammonia excretion post-feeding were significantly steeper for the 47/18 diet suggesting a larger, quicker post-prandial ammonia insult on the culture system. Thirdly, nutrient and energy retentions were markedly poorer in the $47 \%$ digestible protein diets regardless of lipid level. Finally, ammonia production from the $47 / 18$ diet did not change appreciably with ration level when calculated on a $\mathrm{g} \mathrm{N}$ consumed per BW basis. In contrast, ammonia production with respect to $\mathrm{N}$ fed/kg BW was nearly equal between the 40/18 and 33/18 diets at restricted feeding, but still greater than that observed at satiation. At satiation feeding, TAN excretion on a nitrogen fed per body weight basis was much lower in fish fed the 40/18 diet when compared to fish fed the 33/18 diet, and the magnitude of decreases from restricted feeding differed markedly: nearly $30 \%$ decrease in fish fed the $40 / 18$ diet, but just $16 \%$ decrease in fish fed the $33 / 18$ diet. Restricting feed to $80 \%$ of satiation slightly improved feed conversions and protein and amino acid retentions over satiation feeding; however, the effect was less than 2.5 percentage points on protein and amino acid retentions across the board and nearly equal between the 33/18 and 40/18 diets. At least part of the statistical differences in retention efficiencies between rations can be attributed to a slight improvement in utilization of the $47 / 18$ diet when fed to less than satiation. However, protein and amino acid retentions were almost always numerically highest in those fed the 40/18 to satiation. These data suggest that additional research is needed to determine if protein and amino acid retentions will separate more distinctly among diets of differing protein to energy ratios when sunshine bass are reared at elevated temperature to market size ( $\geq 800 \mathrm{~g}$ ). Practically, the improvement in feed conversion seen at restricted feeding only amounted to a tenth of a gram less feed on average per gram gained. The lowest feed consumption as a percent of body weight (ADI) and lowest feed conversion ratios were consistently observed in fish fed the 40/18 diet. Interestingly, Glencross and Rutherford (2010) found that increasing the dietary protein to energy ratio from 21 to $26 \mathrm{~g} / \mathrm{MJ}$, similar to the range employed in the current study, did not significantly alter feed intake in barramundi, Lates calcerifer, reared at 30 or $37^{\circ} \mathrm{C}$, but did decrease FCR. On the other hand, Green et al. (2011) observed that both ADI and FCR in South African abalone decreased with increasing dietary protein to energy density ratio at elevated culture temperature. Similarly, we also found concomitant reductions in ADI and FCR in sunshine bass in response to increasing dietary protein to energy ratio up to the 40/18 diet.

The observations that body fat (IPF), muscle mass (MR), and whole body protein were lower, while livers were much larger (> HSI), in fish fed the 33/18 diet are consistent with our previous short-term results at elevated temperature (Rawles et al., 2010). Rawles et al. (2010) also found (see Table 7) that IPF, and liver size were sensitive indicators of dietary protein and fat level at 29 and $32^{\circ} \mathrm{C}$. For example, livers from hybrid striped bass fed diets of lower nutrient density (e.g. 35/10) had larger livers than fish fed diets of higher nutrient density (e.g., 40/15), which is similar to the longer term results in the current study. On the other hand, while muscle ratio at 35 or $40 \%$ crude protein did not differ in our previous study, even small differences in muscle ratio among diets and rations were discernible in the current study. Thus, the compositional data from this study indicate insufficient diet energy to optimize growth and maintain body depots of energy at 33\% DP and 18\% dietary lipid at $30.5^{\circ} \mathrm{C}$, regardless of ration level.

Early in literature, Elliott (1976) and Brett and Groves (1979) pointed out that feeding restricted rations to fish at different temperatures results in lower growth efficiencies at higher temperature because "growth has the lowest immediate priority", i.e., at higher temperature a greater portion of metabolizable energy is allocated to maintenance requirements and metabolic expenditures than to growth. Subsequent data from salmonids have shown that protein digestibility decreases, endogenous protein turnover increases, and endogenous protein synthesis decreases at elevated temperature (Barnes et al., 2006; Carter et al., 2006). All production parameters, nutrient retentions, as well as 
body composition and compositional indices of fish fed the 33/18 relative to the other $18 \%$ lipid diets are consistent with these findings. Hence, at $33 \% \mathrm{DP}$ and $18 \%$ fat the proportion of ingested protein used for maintenance, turnover, and activity, as opposed to muscle accretion would increase, and the proportion of dietary lipid that could spare amino acids for growth would decrease relative to the $40 / 18$ diet.

The responses to the $47 / 18$ diet in the current study are interesting in that weight gain and final fish weight were maximal at this highest diet energy density tested, while FCR, body composition and nutrient retentions point to poorer metabolic efficiency and lower nutrient stores in combination with much greater feed consumption. Guerreiro et al. (2011) found a similar hyperphagia combined with poorer FCR and nutrient retentions in Senegalese sole fed an energy dense diet containing 55\% crude protein and 16\% lipid, while a similar phenomenon has been observed in another moronid, European sea bass Dicentrarchus labrax (Peres and Oliva-Teles, 1999). If protein synthesis and protein digestibility decrease with high culture temperature and thermal stress, then it follows that overconsumption of a high-protein, high-fat diet in an attempt to meet metabolic needs would result in markedly poorer FCR and retention efficiencies. However, the reasons behind the hyperphagia are elusive; Guerreiro et al. (2011) speculated that control of feed intake may somehow be deregulated by the interaction of high lipid, high protein and increased temperature.

Glencross and Rutherford (2010) postulated that due to increased protein turnover at higher temperature the demand for some amino acids in fish may increase more than others and that histidine was one candidate for observation due to the connection between thermal stress, cataracts, and His deficiency (Breck et al., 2005). Similar to the current results, Glencross and Rutherford (2010) found improved protein and amino acid (i.e., His and Lys) retention with increasing dietary protein and energy. However, histidine retention from the diet they supplemented with His was actually poorer than that of the reference (REF) diet or the higher protein to energy (PRO) diet, whereas Lys retention was unaffected by His supplementation. These observations beg the question of whether Lys and Met supplementation in the current study affected other essential amino acid retentions.

In general, the pattern of retention efficiencies among most of the amino acids measured in this study was similar with respect to ration, lipid level, and DP level and expressed identical lipid x DP interaction. The retentions of Met and Arg differed somewhat, however, due to significant interaction of ration with lipid level. Among most amino acids, including Lys and His, retentions in fish fed 33\% DP did not differ significantly from those fed 40\% DP; however, amino acid retentions in fish fed $47 \%$ DP were significantly lower. This pattern was consistent between ration and dietary lipid levels, although there was more statistical overlap with retentions of the $47 \%$ DP diet at $10 \%$ dietary lipid. In the case of Met, however, feeding the low fat (10\%) diets to satiation improved Met retention sufficiently to cause means separation among DP levels, suggesting that Met may have been over supplemented to some extent, or that metabolic demands for Met for functions other than muscle accretion were lower for the low fat vs. high fat diets. In the case of Arg retention, however, there were no differences among DP levels at $10 \%$ lipid, and satiation feeding did not change this fact. This suggests that available Arg levels in the diet may have been marginally deficient since absolute levels in the diets were slightly lower than target levels in the muscle (Table 2). Alternatively, it is possible that Lys-Arg antagonism lowered Arg availability since absolute levels of Lys in the diets (Table 2) were $40 \%$ higher than muscle levels due to Lys supplementation (Balnave et al., 1999).

The range of daily postprandial ammonia excretion measured in the present experiment was similar to that observed in a previous hybrid striped bass (HSB) study (Rawles et al., 2009) and in European sea bass (Robiana et al., 1999), and falls along the continuum of reported ranges for other fish (Beamish and Thomas, 1984; Dosdat et al., 1996; Fournier et al., 2003; Kaushik, 1980; Leung et al., 1999). The pattern of postprandial ammonia excretion in the present experiment was consistent with previous reports for HSB (Rawles et al., 2009) and European sea bass (Ballestrazzi et al., 1998; Dosdat et al., 1996; Robiana et al., 1999). In fact, ammonia excretion by fish peaks from $2-10 \mathrm{~h}$ following a meal and is affected by fish size and water temperature (Cheng et al., 2005; Dosdat et al., 1996; Forsberg, 1997; Leung et al., 1999; Liu et al., 2009; Luo and Xie, 2009). The amounts of N intake excreted as ammonia following a meal in the present experiment were consistent with the ranges reported for a variety of fish tested under a range of experimental conditions (Beamish and Thomas, 1984; Cheng et al., 2005; Dosdat et al., 1996; Forsberg, 1997; Kaushik, 1980; Luo and Xie, 2009; Rawles et al., 2009; Robiana et al., 1999).

Consistent with published research on other freshwater and marine fish, postprandial ammonia excretion in the present study was positively related to dietary protein content and protein intake. Ammonia excretion by rainbow trout (Oncorhynchus mykiss) (Beamish and Thomas, 1984; Dosdat et al., 1996), Palmetto bass (Morone saxatilis x M. chrysops) (Liu et al., 2009), mullet (Mugil platanus) (de Carvalho et al., 2010), cobia (Rachycentron canadum) (Sun et al., 2006), Atlantic salmon (Forsberg, 1997), and European sea bass (Boujard et al., 2004; Dosdat et al., 1996; Robiana et al., 1999) increased with increasing dietary protein content or intake, even in fish fed restricted rations (Forsberg, 1997).

Soluble reactive phosphorus excretion by HSB was low in the present study. Consistent with Kaushik et al. (2004), we found low soluble reactive $P$ concentrations in tank influent and effluent. While no other published reports on soluble P excretion by HSB were found, several papers report on soluble P excretion by European sea bass (Ballestrazzi et al., 1994, 1998; Boujard et al., 2004; Kaushik et al., 2004). As with our results for HSB, soluble P excretion by European sea bass did not vary with protein content (Ballestrazzi et al., 1994) or ration size (Boujard et al., 2004). On the other hand, dietary lipid content and soluble P excretion by European sea bass were inversely related as dietary lipid increased from 11-30\% (Boujard et al., 2004); however, we found no such correlation in hybrid striped bass at elevated temperature.

It is essential to formulate diets that optimize $\mathrm{N}$ and $\mathrm{P}$ utilization and minimize metabolic losses to the environment. Nitrogen losses as ammonia can present toxicity problems to pond-reared HSB during summer months when feeding rates and water temperatures are high. Additionally, metabolic losses of $\mathrm{N}$ and $\mathrm{P}$ from feeding stimulate dense phytoplankton blooms, which increase the complexity of daily pond management. Dietary protein is spared by including carbohydrate or lipid in the diet (Fynn-Aikins et al., 1995). Increasing dietary lipid from 10\% to $18 \%$ improved protein utilization in the present experiment as evidenced by the significantly lower ammonia excretion rates observed in fish fed $18 \%$ lipid diets. Ammonia excretion by grouper (Epinephelus coioides) decreased when dietary lipid content was increased (Cheng et al., 2005). However, a significant protein sparing effect was not detected in rainbow trout fed 35 or $49 \%$ protein diets that contained 10 or $20 \%$ lipid (Beamish and Thomas, 1984).

Therefore, from the standpoint of practical management during summer production of hybrid striped bass, the current results imply that it is possible to manipulate both fish performance and waste excretion to positive benefit using dietary strategies. Secondly, it would appear from these results that there is little advantage to reducing both digestible protein from 40 to $33 \% \mathrm{DP}$ ( 46 to $38 \% \mathrm{CP}$ ) and feed ration, at the same time, during the heat of summer. If pond ammonia nitrogen is very high, for example, one might be tempted to feed the lower protein $(38 \% \mathrm{CP})$ diet at restricted ration, since there was some reduction in TAN excretion with the $33 \%$ DP diets. The results suggest, however, that the reductions in growth and feed performance seen among the current set of diets at $80 \%$ satiation would be exacerbated at more severe levels of feed restriction. Hence, a producer desiring to reduce pond ammonia with the least compromise to production efficiency would be better served to continue feeding the $40 \%$ DP ( $46 \%$ CP) / $18 \%$ lipid diet at a reduced level instead of switching to a lower protein diet. 


\section{Acknowledgments}

We gratefully acknowledge the following individuals and companies for their material contributions to this research: Hybrid striped bass Mike Freeze, Keo Fish Farms, Inc; Poultry products - Chuck Malone, Tyson Foods, Inc.; Menhaden fish oil - Nancy Near, Omega Protein, Inc.; Menhaden fish meal, Select ${ }^{\mathrm{TM}}$ - Jim Stewart, Omega Protein, Inc.; Soybean meal - Archer Daniels Midland Co.; Wheat starch -Manildra Milling, Inc.; DL-Methionine and Lysine- $\mathrm{HCl}$ - ADM Alliance Nutrition, Inc. We also thank the following USDA/ARS personnel for their substantial efforts toward daily animal husbandry, sampling, and chemical analyses: Rebecca Jacobs, Wade Wilson; as well as Troy Bader, Matt Barnett, Bradley Farmer, Bobby Kelly, and Greg O'Neal for their timely help during tissue and ammonia sampling. Finally, USDA/ARS technician Jason Frost was instrumental in extruding the high quality test diets.

Mention of trade names or commercial products in this article is solely for the purpose of providing specific information and does not imply recommendation or endorsement by the U.S. Department of Agriculture. This study was funded by the USDA/ARS under project number 6225-31630-006-00D. USDA is an equal opportunity provider and employer.

\section{References}

AOAC (Association of Official Analytical Chemists), 2005. AOAC Official Methods, 18th edition. Association of Official Analytical Chemists, Incorporated, Arlington, VA. 2,364 pp.

AOCS (American Oil Chemists Society), 2009. Official Methods and Recommended Practices of the American Oil Chemists Society, 6th edition. American Oil Chemists Society, Champaign, IL. 1,200 pp.

Ballestrazzi, R., Lanari, D., D'Argaro, E., Mion, A., 1994. The effect of dietary protein level and source on growth, body composition, total ammonia and reactive phosphate excretion of growing sea bass (Dicentrarchus labrax). Aquaculture 127, 197-206.

Ballestrazzi, R., Lanari, D., D'Argaro, E., 1998. Performance, nutrient retention efficiency, total ammonia and reactive phosphorus excretion of growing European sea-bass (Dicentrarchus labrax L.) as affected by diet processing and feeding level. Aquaculture 161, 55-65.

Balnave, D., Hayat, J., Brake, J., 1999. Dietary arginine:lysine ratio and methionine activity at elevated environmental temperatures. Journal of Applied Poultry Research 8 , $1-9$.

Barnes, J.C., Hauler, R.C., Carter, C.G., 2006. The effect of protein: energy ratio on the growth and protein synthesis of Atlantic salmon (Salmo salar) at $19{ }^{\circ} \mathrm{C}$. Proceedings of the International Society for Fish Nutrition and Feeding, p. 56, Biarritz, France, 28 May-1 June, INRA, St. Pee Sur Nuvelle, France.

Barrows, F.T., Gaylord, T.G., Sealey, W., Rawles, S.D., 2011. Database of Nutrient digestibility's of traditional and novel feed ingredients for trout and hybrid striped bass, http://www.ars.usda.gov/Main/docs.htm?docid=21905 2011 Last accessed on $09 / 27 / 11$.

Beamish, F.W.H., Thomas, E., 1984. Effects of dietary protein and lipid on nitrogen losses in rainbow trout, Salmo gairdneri. Aquaculture 41, 359-371.

Boujard, T., Gelineau, A., Coves, D., Corraze, G., Dutto, G., Gasset, E., Kaushik, S., 2004. Regulation of feed intake, growth, nutrient and energy utilization in European sea bass (Dicentrarchus labrax) fed high fat diets. Aquaculture 231, 529-545.

Breck, O., Bjerkas, E., Campbell, P., Rhodes, J.D., Sanderson, J., Waagbo, R., 2005. Histidine nutrition and genotype affect cataract development in Atlantic salmon, Salmo salar L. Journal of Fish Diseases 28, 357-371.

Brett, J.R., Groves, T.D.D., 1979. Physiological energetics. In: Hoar, W.S., Randall, D.J., Brett, J.R. (Eds.), Fish Physiology, vol. III. Academic Press, New York, NY, pp. 279-352.

Buentello, J.A., Gatlin III, D.M., Nelly, W.H., 2000. Effects of water temperature and dissolved oxygen concentration on daily feed consumption, feed utilization and growth of channel catfish (Ictalurus punctatus). Aquaculture 182, 339-352.

Carter, C.G., Bridle, A.R., Ketersky, R.S., Barnes, J.C., Hauler, R.C., 2006. Influence of nutrition and thermal stress on protein synthesis and degradation in fish. Proceedings of the International Society for Fish Nutrition and Feeding. INRA, St. Pee Sur Nuvelle, France, p. 57. Biarritz, France28 May-1 June.

Cheng, A.-C., Tsai, H.-C., Liou, C.-H., 2005. Effects of replacing the energy from fishmeal protein with different energy sources on the growth and ammonia excretion of the orange-spotted grouper (Epinephelus coioides) in two feeding regimes. Journal of The Fisheries Society of Taiwan 32, 327-340.

de Carvalho, C.V.A., Bianchini, A., Tesser, M.B., Sampaio, L.A., 2010. The effect of protein levels on growth, postprandial excretion and tryptic activity of juvenile mullet Mugil platanus (Günther). Aquaculture Research 41, 511-518.

Dosdat, A., Servais, F., Metailler, R., Huelvan, C., Desbruyeres, E., 1996. Comparison of nitrogenous losses in five teleost fish species. Aquaculture 141, 107-127.

Elliott, J.M., 1976. The energetics of feeding, metabolism and growth of brown trout (Salmo trutta L.) in relation to body weight, water temperature, and ration size. Journal of Animal Ecology 45, 923-948.
Forsberg, O.I., 1997. The impact of varying feeding regimes on oxygen consumption and excretion of carbon dioxide and nitrogen in post-smolt Atlantic salmon Salmo salar L. Aquaculture Research 28, 29-41.

Fournier, V., Gouillou-Coustans, M.F., Metailler, R., Vachot, C., Moriceau, J., Le Delliou, H., Huelvan, C., Desbruyeres, E., Kaushik, S.J., 2003. Excess dietary argenine affects urea excretion but does not improve $\mathrm{N}$ utilization in rainbow trout Oncorhynchus mykiss and turbot Psetta maxima. Aquaculture 217, 559-576.

Fynn-Aikins, K., Hughes, S.G. Vandenberg, G.W., 1995. Protein retention and liver aminotransferase activities in Atlantic salmon fed diets containing different energy sources. Comparative Biochemistry and Physiology 111A, 163-170.

Gaylord, T.G., Rawles, S.D., 2005. The modification off poultry by product meal for use in hybrid striped bass Morone chrysops x M. saxatilis diets. Journal of the World Aquaculture Society 36, 365-376.

Genfa, Z., Dasgupta, P.K., 1989. Fluorometric measurement of aqueous ammonium ion in a flow injection system. Analytical Chemistry 61, 408-412.

Glencross, B., Rutherford, N., 2010. Dietary strategies to improve the growth and feed utilization of barrramundi, Lates calcarifer under high water temperature conditions. Aquaculture Nutrition 16, 343-350.

Green, A.J., Jones, C.L.W., Britz, P.J., 2011. The protein and energy requirements of farmed South African abalone Haliotis midae L. cultured at optimal and elevated water temperatures. Aquaculture Research 1-11 (DOI: http://dx.doi.org/10.1111/ j.1365-2109.2010.02759.x; Article first published online: February 9, 2011).

Guerreiro, I., Peres, H., Castro-Cunha, M., Oliva-Teles, A., 2011. Effect of temperature and dietary protein/lipid ratio on growth performance and nutrient utilization of juvenile Senegalese sole (Solea senegalensis). Aquaculture Nutrition DOI: http:/ dx.doi.org/10.1111/j.1365-2095.2011.00884.x, pp. 1-9, Article first published online: July 12, 2011.

Hanks, D.M., Secor, D.H., 2011. Bioenergetic responses of Chesapeake Bay white perch (Morone americana) to nursery conditions of temperature, dissolved oxygen, and salinity. Marine Biology 158, 805-815.

Hargreaves, J.A., Kucuk, S., 2001. Effects of dial un-ionized ammonia fluctuation on juvenile hybrid striped bass, channel catfish and blue tilapia. Aquaculture 195, 163-181.

Henderson, J.W., Ricker, R.D., Bidlingmeyer, B.A., Woodward, C., 2006. Rapid, accurate sensitive, and reproducible HPLC analysis of amino acids. Application Note No. 5980-1193EN, Agilent Technologies, Wilmington, DE, http://www.chem.agilent. com/Library/applications/AAA\%20technote.pdf 2006 last accessed September 29, 2011

Kaushik, S.J., 1980. Influence of nutritional status on the daily patterns of nitrogen excretion in the carp (Cyprinus carpio L.) and the rainbow trout (Salmo gairdneri R.). Reproduction Nutrition Development 20, 1751-1765.

Kaushik, S.J., Coves, D., Dutto, G., Blanc, D., 2004. Almost total replacement of fish meal by plant protein sources in the diet of a marine teleost, the European seabass, Dicentrarchus labrax. Aquaculture 230, 391-404.

Leung, K.M.Y., Chu, J.C.W., Wu, R.S.S., 1999. Effects of body weight, water temperature and ration size on ammonia excretion by the areolated grouper (Epinephelus areolatus) and mangrove snapper (Lutjanus argentimaculatus). Aquaculture 170, 215-227.

Liu, F.-G., Yang, S.-D., Chen, H.-C., 2009. Effect of temperature, stocking density and fish size on the ammonia excretion in palmetto bass (Morone saxatilis $\mathrm{x}$ M. chrysops). Aquaculture Research 40, 450-455.

Luo, Y., Xie, X., 2009. The effect of temperature on post-feeding ammonia excretion and oxygen consumption in the southern catfish. Journal of Comparative Physiology. B 179, 681-689.

Najjar, R.G., Pyke, C.R., Adams, M.B., Breitburg, D., Hershner, C., Kemp, M., Howarth, R., Mulholland, M.R., Paolisso, M., Secor, D., Sellner, K., Wardrop, D., Wood, R., 2010 Potential climate-change impacts on the Chesapeake Bay. Estuarine, Coastal and Shelf Science 86, 1-20.

Peres, H., Oliva-Teles, A., 1999. Influence of temperature on protein utilization in juvenile European sea bass (Dicentrarchus labrax). Aquaculture 170, 337-348.

Rawles, S.D., Gaylord, T.G., McEntire, M.E., Freeman, D.W., 2009. Evaluaiton of poultry by-product meal in commercial diets for hybrid striped bass, Morone chrysops 우 $\mathrm{x}$ Morone saxatilis $\sigma^{7}$, in pond production. Journal of the World Aquaculture Society 40, 141-156.

Rawles, S.D., Gaylord, T.G., Snyder, G.S., Freeman, D.W., 2010. The influence of protein and energy density in commercial diets on growth, body composition, and nutrient retention of sunshine bass, morone chrysops $+\times$ morone saxatilis ${ }^{7}$, reared at extreme temperature. Journal of the World Aquaculture Society 41 (S2), 165-178.

Rayner, C.J., 1985. Protein hydrolysis of animal feeds for amino acid content. Journal of Agricultural and Food Chemistry 33, 722-725.

Robiana, L., Corraze, G., Aguirre, P., Blanc, D., Melcion, J.P., Kaushik, S., 1999. Digestibility, postprandial ammonia excretion andselected plasma metabolites in European sea bass (Dicentrarchus labrax) fed pelleted or extruded diets with or without wheat gluten. Aquaculture 179, 45-56.

Sokal, R.R., Rohlf, F.J., 1995. Biometry: The Principles and Practice of Statistics in Biological Research, Third edition. W. H. Freeman and Company, New York, NY. 887 pp.

Sun, L., Chen, H., Huang, L., Wang, Z., 2006. Growth, faecal production, nitrogenous excretion and energy budget of juvenile cobia (Rachycentron canadum) relative to feed type and ration level. Aquaculture 259, 211-221.

Thomas, S.L., Piedrahita, R.H., 1998. Apparent ammonia-nitrogen production rates of white sturgeon (Acipenser transmontanus) in commercial aquaculture systems Aquacultural Engineering 17, 45-55. 